\title{
COMMENT
}

\section{The Implications of the New Community Property Laws for Creditors' Remedies and Bankruptcy}

\begin{abstract}
Alan Pedlar†
Seven of the eight community property states have recently amended their laws to provide spouses with equal managerial rights in their community property. This Comment focuses on the problems and ramifications this change creates in the areas of creditors' remedies and bankruptcy in California, and includes a survey of the other community property states. Finally, the proposed bankruptcy acts are examined in light of the new community property laws and suggested revisions are presented which will facilitate equal treatment of the spouses and their creditors in bankruptcy.
\end{abstract}

Against the background of developing judicial scrutiny of sexbased discrimination ${ }^{1}$ and a pending constitutional amendment ${ }^{2}$ that

Copyright (C) 1975, Alan Pedlar

$\dagger$ B.S. 1971, University of California, Los Angeles; M.S. 1973, Stanford University; third-year student, Boalt Hall School of Law; Head Article Editor, California Law Review.

The author gratefully acknowledges the substantive suggestions of Professor Stefan A. Riesenfeld and is honored to be able to participate in this tribute to him.

1. E.g., Frontiero v. Richardson, 411 U.S. 677 (1973); Reed v. Reed, 404 U.S. 71 (1971); Sail'er Inn v. Kirby, 5 Cal. 3d 1, 485 P.2d 529, 95 Cal. Rptr. 329 (1971). A strong argument can be made that the community property laws of California prior to 1975 denied the wife equal protection of the law under the 14th Amendment of the United States Constitution. Comment, Equal Rights and Equal Protection: Who Has Management and Control?, 46 S. CAI. L. REv. 892 (1973); Note, The Equal Rights Amendment and Inequality Between Spouses Under the California Community Property System, 6 Loyola L. Rev. (Los ANgeres) 66 (1973); Note, Management and Control of Community Property: Sex Discrimination in California, 6 U.C.D.L. REv. 383 (1973). For a listing of similar articles discussing the constitutionality of community property laws in other states, see Reppy, Retroactivity of the 1975 California Community Property Reforms, 48 S. CaL. L. REv. 977, 979 n.2 (1975) [hereinafter cited as Reppy]. One of the motivations for reforming the conmunity property law in California was the legislature's concern that the old act was subject to constitutional attack. Id. at 980 n.5.

2. The proposed Amendment provides:

1. Equality of rights under the law shall not be denied or abridged by the Urited States or by any State on account of sex. 
would expressly prohibit sex-based discrimination, the legislatures of seven of the eight community property states have extensively revised their community property laws. ${ }^{3}$ This Comment will utilize California's new community property law $^{4}$ as a vehicle for discussing the interrelationship between the new "equal management and control" community property laws and the administration of a bankrupt's estate under the Bankruptcy Act. ${ }^{5}$ It will then discuss the proposed bankruptcy acts ${ }^{6}$ insofar as they deal with community property.

According to the data available for the fiscal year ending June 30 , 1974, there were 157,967 straight bankruptcies filed in the United States during the preceding 12 month period. ${ }^{7}$ Of these, 30,000 cases represents a crude estimate of the nuniber of proceedings commenced in community property states. ${ }^{8}$ A rough estimate places the number of

2. The Congress shall have the power to enforce, by appropriate legislation, the provisions of this article. tion.

3. This amendment shall take effect two years after the date of ratifica-

H.R.J. Res. 208, 92d Cong., 2d Sess. (1972). California ratified the amendment Nov. 17, 1972. Res. ch. 148, [1972] 2 Cal. Stat. 3440 . To date, 34 states have ratified the amendment. N.Y. Times, May 20, 1975, $\S 1$, at 17, col. 1 . Ratification by 38 states is required. U.S. CoNST. art. V.

3. ARz. Rev. STat. $\S \S 25-211$ to -215 (Supp. 1973); CAL. CIv. Code $\S \S 5100$ 5132 (West Supp. 1975); Idako CODE $\$ \S 32-901$ to -912 (Supp. 1975); Nev. REv. Stat. $\S \S 123.010$ to -.250 , ch. 393, $\S \S 1-18$, [May 10, 1975] Nev. Stat. 557-62 (Advance Sheets); N.M. STAT. \$\$ 57-4A-1 to $-4 A-8$ (Supp. 1973 and Interim Supp. 1975); TEX. FAM. CODE $\S \S 5.01-.02,5.21-.25,5.61-.62$ (1975); WASH. Rev. CODE $\S \S 26.16 .010$ $.16 .040,26.16 .190-16.200$ (Supp. 1974). Only Louisiana adheres to the system of sole management of the community property by the husband. LA. Civ. CODE arts. 2399-404 (1971).

4. The legislation was primarily enacted in ch. $987, \S \S 2-17$, [1973] 1 Cal. Stat. 1897 and revised by ch. 1206, $\$ \S 1-7$, [1974] Cal. Stat. - [hereinafter referred to together as the new community property law]. For a general discussion of the new community property law, see Kahn \& Frimmer, Management, Probate and Estate Planning Under California's New Community Property Laws, 49 CaL. ST. B.J. 516 (1974) [heremafter cited as Kahn \& Frimmer]; Reppy, supra note 1; Comment, Tort Debts Versus Contract Debts: Liability of the Community Under California's New Community Property Law, 26 HAST. L.J. 1575 (1975); Comment, California's New Community Property Law-Its Effect on Interspousal Mismanagement Litigation, 5 PaC. L.J. 723 (1974); Comment, Equal Management and Control Under Senate Bill 569: "To Have and to Hold" Takes on New Meaning in California, 11 SAN DIEgo L. REv. 999 (1974). 544.

5. 11 U.S.C. \$§ 1-1255 (1970), amending Act of July 1, 1898, ch. 541, 30 Stat.

6. Presently, two bankruptcy bills are before Congress. One represents the report of the Commission on the Bankruptcy Laws of the United States, H.R. 31, 94th Cong., 1st Sess. (1975) [hereinafter cited as the Proposed Act], and the other is commonly known as the Judges' Bill, H.R. 32, 94th Cong., 1st Sess. (1975). The provisions dealing with community property in the Judges' Bill are identical to those of the Proposed Act. All references will be to the Proposed Act.

7. S. Riesenfeld, Creditors' Remedies and Debtors' Protection 474 (2d ed. 1975).

8. Over 20 percent of the population of the United States reside in states which 
estates distributing assets to unsecured creditors in these 30,000 cases at over $7,000 .{ }^{9}$ Yet, in view of the drastic changes in the community property laws of these states, the case law discussing distribution of the bankrupt's estate is largely obsolete because it was developed during the era of the husband's sole nuanagement and control of the community property. It is thus time for a fresh examination of admimistration of the bankrupt's estate involving community property.

Part I of this Comment reviews the historical developinent in California of spouses' interests in community property and of the rights of their creditors prior to the enactment of the new community property law. This treatment is then used to rationalize the bankruptcy decisions in California prior to January 1, 1975 and to demonstrate the interrelationship between the state community property system and the Bankruptcy Act. Part II discusses spouses' rights to equal management and control of community property under the new community property law and the concurrent expansion of the rights of their creditors which relate to administration of the bankrupt's estate. Unsettled questions that arise under the new commumity property law in the area of creditors' remedies are also discussed. Part III describes the problems presented by the interrelationship between the new community property law and the Bankruptcy Act. It is evident that the primary object of bankruptcy law in a community property state is no longer to secure a just distribution of the bankrupt's assets among his creditors; ${ }^{10}$ rather, it is to secure a just distribution among creditors of both spouses. However, the statutory means for accomplishing this result is not readily apparent. This Comment suggests that the bankruptcy court, as a court of equity, has at least two options available to it whereby it may construe the Bankruptcy Act in order to accomplish an equitable distribution of the bankrupts assets. Part IV briefly discusses the community property laws of the other six states that have adopted equal managenient and control of the community property by the spouses and tests the flexibility of the solution proposed in Part III for administration of the bankrupt's estate in California by applying it to the variations presented by the comniunity property laws of the other states. Finally, Part V comments briefly on the sections of the Proposed Act that deals with community property. Because these sections were drafted before the flurry of statutory amendments in the community property states occurred, the proposals inadequately deal with the administration of the bankrupt's estate under

have adopted community property as the means of marital landownership. U.S. DEP'T of Commerce, Bureau of the Census, Statistical Abstract of the U.S. 12 (1974).

9. Approximately 25 percent of the straight bankruptcy cases filed eventually dis* tribute assets to unsecured creditors. D. Stanley \& M. GIRTH, Bankruptcy: Problem, PROCESS, REFORM 92-93 (1971).

10. See, e.g., Wilson v. City Bank, 84 U.S. (17 W'all.) $473,481-82$ (1873). 
the new equal management statutes. For this reason, alternative language is suggested for the Proposed Act, followed by a brief treatment of bankruptcy administration in California under this proposal.

\section{I}

\section{The former Community Property LaW IN CALIFORNIA}

\section{A. The Interests of the Spouses}

The community property system of marital landownership was brought to California by the Spanish ${ }^{11}$ and was incorporated in the first constitution of California. Article XI, section 14, adopted in 1849, embodied the basic concept of a community property system:

All property, both real and personal, of the wife, owned or claimed by her before marriage, and that acquired afterwards by gift, devise, or descent, shall be her separate property: and laws shall be passed more clearly defining the rights of the wife, in relation as well to her separate property, as to that held in common with her husband. Laws shall also be passed providing for the registration of the wife's separate property. ${ }^{12}$

The following year the legislature enacted statutes defining the rights of the wife in her separate property and in the community property. The husband was given management and control of the wife's separate property, but he did not have the power to alienate or encumber it unilaterally. ${ }^{13}$ Management and control of the common (community) property, including the absolute power of disposition, rested entirely with the husband. ${ }^{14}$ On the death of either spouse, one-half of the

11. The "ganancial" or community property system in Spain can be traced in written form to the Visigothic Code of 693 A.D., certainly predating common law property concepts. W. deFuniak \& M. Vaughn, Principles of Community Property 34 (2d ed. 1971) [hereinafter cited as DEFuniaK \& VAUGHN]. The concept and development of a community property system may be traced as far back as ancient Egypt. Id. at 15. Also see Loewy, The Spanish Community of Acquests and Gains and Its Adoption and Modification by the State of California, 1 CALIF. L. REv. 32 (1912).

12. CAL. Const. art. XI, $\S 14$ (1849). There is some indication that the community property system was embodied in the newly formed nation's constitution to place it beyond the reach of the legislature. DEFUNIAK \& VAUGHN, supra note 11, at 85 . For a description of the constitutional convention debates, see McMurray, The Beginnings of the Community Property System in California and the Adoption of the Common Law, 3 CALIF. L. Rev. 359, 369-73 (1915).

13. Ch. 103, § 6, [1850] Cal. Stat. 254 (repealed 1872).

14. Ch. $103, \S 9,[1850]$ Cal. Stat. 254 (repealed 1872 but embodied in the California community property system until January 1, 1975). The original community property statutes were effectively repealed by enactment of the Field Code on March 21,1872 . The new community property provisions were ennbodied in the 100 series of the Civil Code. These were in turn repealed effective January 1, 1970 and largely reenanter in the 5100 series of the Civil Code as a portion of the Family Law Act, CaI. 
community property passed to the survivor and the other half passed to the deceased's descendants, or in the absence of such descendants, to the surviving spouse..$^{15}$ Upon dissolution of marriage, the community property was to be divided evenly. ${ }^{16}$ It was this statutory framework that evolved into the community property system of California. ${ }^{17}$

Judicial construction of the community property laws from 1850 to 1917 was erratic, as judges weaned on common law property concepts attempted to deal with community property principles. ${ }^{18}$ Although few changes occurred in the statutory language, ${ }^{19}$ the courts variously described the wife's interest as an equitable right in one-half of the property, ${ }^{20}$ a present and definite joint legal interest in the property, ${ }^{21}$ an interest so vested that the husband could not deprive the wife of it by will, ${ }^{22}$ and a mere expectancy, like that of an heir. ${ }^{23}$ The "mere expectancy" doctrine-leaving full legal title in the husband-ultimately prevailed, ${ }^{24}$ despite an 1891 amendment to former Civil Code section 172 that required the wife's written consent to all gifts of community property by the husband. ${ }^{25}$

Civ. CoDE $\$ \S 5100-38$ (West 1970), as amended, CAL. CTv. CoDe $\S \S 5100-38$ (West Supp. 1975). The new community property law is an amendment of the statutes contained in the 5100 series of the Civil Code. In the remainder of this Comment, subseqnent history of statutes cited will not be given unless relevant.

15. Ch. 103, \& 11, [1850] Cal. Stat. 255 (repealed 1872).

16. Ch. 103, \$12, [1850] Cal. Stat. 255 (repealed 1872).

17. The system has remained largely unchanged over 125 years. The wife was given full control over her separate property in 1872. CaL. CTv. Code $\$ 162$ (1872) (now CAL. CTv. CODE $\$ 5107$ (West 1970)). However, she was not given managerial control over the bulk of the community property until 1975. CAL. Civ. CoDE $\$ 5125$ (West Supp. 1975). See text accompanying notes 69-78 infra.

18. The California cases were in such frequent conflict during this era as to cause comment by the courts of other states. DEFUNIAK \& VAUGGN, supra note 11, 264-67. For a review of the major decisions of this time, see Simmons, The Interest of a Wife in California Community Property, 22 CALIF. L. REv. 404 (1934).

19. In 1879 a new state constitution was enacted which did not include the language of section 14 of the constitution of 1849. See text accompanying note 12 supra. Instead, the new constitution provided: "All property, real and personal, owned by either husband or wife, before marriage, and that acquired by either of them afterwards by gift, devise, or descent, shall be their separate property." CAL. CONST. art. XX, $\$ 8$ (1879). This provision implicitly left all other property owned by the husband and wife as cominunity property, for all laws which were previously enacted and not inconsistent with this new constitution remained in force. CAL. CoNST. art. XXII, § 1 (1879). The Field Code, enacted March 21, 1872, had retained the community property system of the 1850 Code.

20. Kashaw v. Kashaw, 3 Cal. 312, 322 (1853).

21. Beard v. Knox, 5 Cal. 252, 256 (1855).

22. DeGodey v. Godey, 39 Cal. 157, 164 (1870).

23. Van Maren v. Johnson, 15 Cal. 308, 311 (1860).

24. Spreckles v. Spreckles, 116 Cal. 339, 345-47, 48 P. 228, 230-31 (1897); Spreckles v. Spreckles, 172 Cal. 775, 782, 158 P. 537, 539 (1916).

25. Ch. 222, \& 1, [1891] Cal. Stat. 425 (now embodied in CaI. Crv. Code $\S \S 5125,5127$ (West Supp. 1975) and applicable to both spouses). 
In 1917, the legislature enacted former Civil Code section 172a, which provided that the wife join in any instrument by which community real property was conveyed, encumbered or leased for a period of more than 1 year. ${ }^{26}$ Nevertheless, the wife continued to lack a present vested interest, ${ }^{27}$ notwithstanding the husband's incapacity to give away community property or sell community realty without her consent, and despite the fact that the wife no longer paid inheritance tax on her half of the community property. ${ }^{28}$

The common law characterization of the wife's interest in the community property as a inere expectancy proved disadvantageous to California citizens as a result of a subsequent tax case. In United States v. Robbins, ${ }^{29}$ a husband and wife had each reported one-half of the husband's earnings to avoid the impact of the progressive tax rates. The Supreme Court, per Justice Holmes, held that the ability to sphit income in this manner was dependent on the local interpretation of the community property law; because the wife's interest was but a mere expectancy in California, the full income was taxable to the husband. ${ }^{30}$ At the next session of the California Legislature, forner Civil Code section 161a was enacted to provide that "[t]he respective interests of the husband and wife in community property during the continuance of the marriage relation are present, existing and equal interests under the management and control of the husband . . . "31 The tax question was soon raised anew and yielded a favorable result for the California taxpayer. ${ }^{32}$ However, in Grolemund v. Cafferata, ${ }^{33}$ the California Supreme Court refused to acknowledge that the legislative revision had vested the wife's interest in community property for any purpose other than taxation..$^{34}$

The interests of the spouses were modified only slightly in the years

26. Ch. 583, § 2, [1917] Cal. Stat. 829 (now embodied in CAL. Crv. CoDe $\S 5127$ (West Supp. 1975).

27. Stewart v. Stewart, 199 Cal. 318, 340-41, 249 P. 197, 206-07 (1926).

28. Ch. 18, § 1, [1923] Cal. Stat. 29-30 (former CaL. CTv. CoDe $\$ 1401$, now embodied in CAL. Prob. Code $\& 201$ (West 1958)). This statute was enacted to reverse the decision in Estate of Moffitt, 153 Cal. 359, 95 P. 653 (1908), aff d, 218 U.S. 400 (1910). See Estate of Phillips, 203 Cal. 106, 111, 263 P. 1017, 1019-20 (1928).

29. 269 U.S. 315 (1926). See U.S. v. MaIcolm, 282 U.S. 792 (1931) and note 32 infra.

30. 269 U.S. at 326-28.

31. Ch. 265, \$ 1, [1927] Cal. Stat. 484.

32. The Ninth Circuit certified the following question to the United States Supreme Court: "1. Under the applicable provisions of the Revenue Act of 1928 must the entire community income of a husband and wife domiciled in California be returned and the income tax thereon be paid by the husband?" Answer: No. "2. Has the wife under $\$ 161$ (a) of the Civil Code of California such an interest in the community income that she should separately report and pay tax on one-half of such income?" Answer: Yes. United States v. Malcolm, 282 U.S. 792, 793-94 (1931).

33. 17 CaI. $2 d$ 679, 111 P.2d 641, cert. denied, 314 U.S. 612 (1941).

34. Id. at $688-89,111 \mathrm{P} .2 \mathrm{~d}$ at 646 . 
between Grolemund (1941) and January 1, 1975. ${ }^{35}$ Thus, although the wife's interest in the community property was characterized as present, existing, and equal prior to January 1,1975 , she had no power to deal with her interest in any way. The husband had absolute control of the community personal property (other than the wife's uncommingled earnings and personal injury damage awards), with gratuitous transfers requiring the wife's written consent. The husband likewise had manageinent and control over the community real property, subject to the wife's written consent to transfers or encumbrances for periods exceeding 1 year. Both spouses had full control of their separate property and the rents, issues and profits derived therefrom..$^{38}$

\section{B. Creditors' Remedies}

California's community property system has never recognized the doctrine of "community" and "separate" debts. ${ }^{37}$ Because the community has never been regarded as an entity capable of incurring obligations, ${ }^{38}$ debts have been attributed to either the husband or the wife. ${ }^{30}$

35. In 1951, the wife was given sole management and control of community property consisting of her earnings and personal injury damages until commingled with community funds. Ch. 1102, § 1, [1951] Cal. Stat. 2860-61 (former Cal. CIv. CoDe $\$ 171 c$ ). In 1957 , personal injury damage awards were made separate property. $\mathrm{Ch}$. 2334, § 1, [1957] Cal. Stat. 4065-66 (former CaL. Civ. Code $\$ 163.5$ ). But in 1969, the wife's personal injury damages were once again gronpsd with her earnings as community property under her sole management and control. Ch. 1608, $\$ 5124$, [1969] Cal. Stat. 3341 (former CAL. CTV. CODE $\$ 5124$ (repealed 1975)).

36. Former CaL. Crv. Code $\$ 172$ (1872) (now CaL. Civ. Code $\$ 5107$ (West 1970)); former CAL. CTv. CoDe $\$ \$ 162-63$ (1872) (now CAL. Civ. Code $\$ 5108$ (West 1970)).

37. DEFUNIAK \& VAUGHN, supra note 11 , at 387.

38. In Washington, the community is considered to have the capacity to incur debts for some purposes. Household Finance Corp. v. Corby, 61 Wash. 2d 184, 186, 377 P.2d 441, 442 (1963). Professor Marsh describes the Washington "community debt" system as follows:

The theory of "community debts," briefly stated, is that the community property is only hable for an obligation of the husband if the husband was acting as an agent of the marital community in the transaction in which the obligation was incurred or if the obligation was incurred for the benefit of the marital community.

Marsh, "California Family Law"-A Review, 42 CaLIF. L. REv. 368, 379 (1954). Thus, in Washington there can be separate debts of the husband which are not community debts and which may not be satisfied from community assets. These include contracts not entered into on behalf of the community, personal torts which result from activities not benefiting the community, and prenuptial debts. DEFUNIAK \& VAUGHN, supra note 11, at 371-87.

39. The court in Grolenund v. Cafferata, 17 Cal. 2d 679, 111 P.2d 641, cert. denied, 314 U.S. 612 (1941) stated:

[T]n California there is no like concept of "community debts," though occasionally the courts in this state refer to such, overlooking the fact that the phrase is not appropriate to the California system. A complete reading of all our code sections on community property clearly demonstrates that our comnunity system is based upon the principle that all debts which are not specifi- 
Thus, under the former law, debts of the husband included those incurred for the benefit of the community as well as for purely personal purposes. ${ }^{40}$ The wife, who lacked powers of inanagennent and control over the community property, could not contract for the community except as an agent of the husband. ${ }^{41}$ These principles determined the inanner in which creditors of the wife or the husband could satisfy their clanins.

\section{Creditors of the Husband}

The Civil Code as adopted in 1872 provided that the earnings of the wife and her separate property were not liable for the debts of the husband. ${ }^{42}$ Implicit in this enactment was the fact that the community property (as well as the husband's separate property) was liable for all debts of the husband. ${ }^{43}$ The hability of the community property for the husband's debts was apparently based upon the husband's control over the cominunity property. ${ }^{44}$ Until the 1975 amendments to the community property laws, the only significant modifications to this basic scheme were those removing the wife's earnings and personal injury damages from the management and control of the husband. ${ }^{45}$ Accordingly, the husband's creditors could reach his separate property and all community property other than the wife's earnings and personal injury damages,

cally made the obligations of the wife are grouped together as the obligations

of the husband and the community property . . . .

Id. at 688,111 P.2d at 645 (citation omitted). Also see Wilson v. Wilson, 33 Cal. $2 \mathrm{~d}$ 107, 110, 199 P.2d 671, 673 (1948).

40. Grolemund v. Cafferata, 17 Cal. $2 \mathrm{~d} 679,688,111$ P.2d 641, 646, cert. denied, 314 U.S. 612 (1941); Street v. Bertolone, 193 Cal. 751, 753, 226 P. 913 (1924).

41. Hulsman v. Ireland, 205 Cal. 345, 270 P. 948 (1928); B. WITKIN, 7 SUmmarry of California Law Community Property $\& 87$ at 5177 (8th ed. 1974); 10 CaL. JUR. 2d Community Property \$ 89 (1964).

42. Ch. 508, § 3, [1937] Cal. Stat. 1497, ch. 544, § 1, [1915] Cal. Stat. 920 (former CaL. Civ. CoDe $\$ \S 168,171$ ). A spouse's separate property continues to be exempt from claims of the other spouse's non-necessity creditors. CAL. Crv. Code $\$$ 5121 (West Supp. 1975); Hansen v. Cramer, 39 Cal. 2d 321, 324, 245 P.2d 1059, 1060 (1952); Newman v. Newman, 268 Cal. App. 2d 895, 898, 74 Cal. Rptr. 444, 446 (2d Dist. 1969).

43. Weinberg v. Weinberg, 67 Cal. 2d 557, 562, 432 P.2d 709, 711, 63 Cal. Rptr. 13, 15 (1967); Grolemund v. Cafferata, 17 Cal. 2d 679, 111 P.2d 641, cert. denied, 314 U.S. 612 (1941); Street v. Bertolone, 193 Cal. 751, 226 P. 913 (1924); General Ins. Co. v. Schian, 248 Cal. App. 2d 555, 558, 56 Cal. Rptr. 767, 769 (1st Dist. 1967). See also Van Maren v. Johnson, 15 Cal. 308 (1860), which was decided under the 1850 community property laws.

44. B. Witkin, 7 Sumanary of Calmornta LaW Community Property $\S 84$ at 5173 (8th ed. 1974) and cases cited therein. Also consider the following: "[T] he basic principle of a managerial system of creditors' rights is that whatever a spouse may voluntarily choose to pay to his or her creditors, the creditors can disgorge from the spouse." Reppy, supra note 1, at 999.

45. Note 35 supra. 
regardless of whether the obligations arose before or after marriage or were founded in tort or contract. ${ }^{46}$

\section{Creditors of the Wife}

The creditors of the wife fared relatively less well prior to 1975 . Former Civil Code section 167 provided that neither the community property nor the luusband's separate property was liable for postnuptial contracts of the wife unless secured by the liusband's pledge or mortgage. ${ }^{47}$ Only the wife's separate property and community property consisting of lier uncommingled earnings and personal injury damages were available to satisfy the claims of lier contract creditors. ${ }^{48}$ The common law rule that the husband was personally liable for the wife's postnuptial torts was changed by the enactment of former Civil Code section 171a in $1913 . .^{40}$ Thereafter the wife was personally liable for lier torts, such liability being satisfied from ler separate property and uncommingled earnings and personal injury damage awards-the community assets under her management and control. ${ }^{50}$ The community property under the management and control of the husband was not liable. ${ }^{.1}$

46. Even broader reach was accorded to creditors who furnished necessities of life to the husband or the wife while they were cohabitating. Such creditors could reach all the community property-regardless of managerial control-and the separate property of both spouses. CAL. Crv. Code $\$ \S 5117,5121$ (West 1970), as amended, CaL. Crv. CoDe $\$ \S 5117,5121$ (West Supp. 1975). See also St. Vincent's Inst. for the Insane v. Davis, 129 Cal. 17, 20, 61 P. 476, 477 (1900).

47. Ch. 612, \& 38, [1873-74] Cal. Stat. 193 (former CaL. Crv. Code $\$ 167$ ); General Ins. Co. v. Schian, 248 Cal. App. 2d 555, 557, 56 Cal. Rptr. 767, 769 (1st Dist. 1967).

48. Ch. 1608, \& 8, [1969] Cal. Stat. 3341 (former CAL. Crv. Code $\$ 5124$ (repealed 1975).

49. Ch. 131, \& 1, [1913] Cal. Stat. 217 (former CaL. Civ. Code $\$ 171 \mathrm{a}$, as amended, CAL. Crv. CODE $§ 5122($ a) (West Supp. 1975)).

50. Note 35 supra; ch. 1608, \& 8, [1969] Cal. Stat. 3341 (former CaL. Civ. Code $\S 5122$ ) as amended, CAL. Crv. Code $\$ 5122$ (West Supp. 1975).

51. It was urged in Smedberg v. Bevilockway, 7 Cal. App. 2d 578, 46 P.2d 820 (1st Dist. 1935), that former CAL. Crv. CoDE $\$ 161$, which gave the wife a vested interest in the community property, rendered her interest im the community property liable for her torts. Id. at 581, 46 P.2d at 821. However, the court avoided this issue and held on narrower ground that community property was not subject to levy by writ of execution by the wife's creditors. Id. at 582, $46 \mathrm{P.2d}$ at 822 . See Grolemund v. Cafferata, 17 Cal. 2d 679, 686, 111 P.2d 641, 644, cert. denied, 314 U.S. 612 (1941) and note 114 infra. Nevertheless, the Califorma Suprene Court in Grolemund read Smedberg as implicitly holding that the community property was not liable for the wife's torts. $17 \mathrm{Cal} .2 \mathrm{~d}$ at $686,111 \mathrm{P} .2 \mathrm{~d}$ at 644 . This result seems inconsistent with the court's position in Grolemund that the community property was liable for the husband's torts, even if committed in the course of his purely personal activities: "Our conclusion in the instant case ... is consonant with practical considerations and public policy as well, for otherwise a person injured by the separate act of the husband would fail to gain redress for his damage in such case where the only property of the spouses is community." Id. at 689, 111 P.2d at 646. Apparently the court did not regard persons in- 


\section{The Bankrupt's Estate}

With the interests of the spouses in the community property and the rights of their creditors in the separate and community property in mind, the composition of the bankrupt's estate prior to 1975 can be examined. Central to this discussion is section $70 \mathrm{a}(5)$ of the Bankruptcy Act, which provides in part:

The trustee of the estate of a bankrupt . . . shall ... be vested by operation of law with the title of the bankrupt as of the date of the filing of the petition initiating a proceeding under this title [Act], except insofar as it is to property which is held to be exempt, to all of the following kinds of property wherever located ... (5) property, including rights of action which prior to the filing of the petition he could by any means have transferred or which might have been levied upon and sold under judicial process against him, or otherwise seized, iinpounded or sequestered $\ldots .{ }^{52}$

The leading case concerning the interrelationship between the husband's estate in bankruptcy and the California community property laws is Hannah v. Swift, ${ }^{53}$ decided before the wife gained management and control over her uncommingled wages and personal imjury damages but after former Civil Code section 161a granted her a present, existing and equal interest in the community property. ${ }^{54}$ In Hannah, the 9th Circuit held first that section 161a did not affect the rights of the husband in the community property, ${ }^{55}$ and then that all of the community property passed to the husband's trustee in bankruptcy. ${ }^{56}$

While the court did not fully explain the rationale for its holding, an examination of section $70 \mathrm{a}(5)$ of the Act and the community property laws at the time of the decision indicates that the holding was

jured by the wife as equally deserving of redress. Nonetheless, in terms of control of the community property and the title theory advanced by the court, the result is correct.

The issue of the liability of the community property for the wife's torts was finally decided in McClain v. Tufts, 83 Cal. App. 2d 140, 187 P.2d 818 (2d Dist. 1947). The court held that tort creditors of the wife could not reach the community property. It should be noted, however, that the community property statutes did not compel this result. Ch. 131, § 1, [1913] Cal. Stat. 217 (former CaL. Crv. CoDe § 171a) merely exempted the husband from liability for postnuptial torts of the wife; it did not exempt the community property.

52. 11 U.S.C. $\S 110$ (a) (5) (1970). While some of the cases that will be discussed were decided before the 1938 annendments to the Bankruptcy Act, no changes were made in the Aet which affected the portion of section $70 \mathrm{a}(5)$ under discussion. 4A Collier ON BANKRUPTCY TाT 70.01, 70.02 at 20-27 (14th ed. 1975).

53. 61 F.2d 307 (9th Cir. 1932).

54. See text accompanying note 31 supra.

55. 61 F.2d at 310 .

56. Id. See Wikes v. Smith, 465 F.2d 1142 (9th Cir. 1972); Martoff v. Elliott, 326 F.2d 204 (9th Cir. 1963); Kirkpatrick v. Harvey, 51 Cal. App. 2d 170, 124 P.2d 367 (4th Dist. 1942); Phelps v. Davies, 126 Cal. App. 419, 14 P.2d 922 (4th Dist. 1932); Gray v. Perlis, 76 Cal. App. 511, 245 P. 221 (1st Dist. 1926). 
correct. In 1932, the husband was vested with full title to all community property, including the wife's earnings and personal injury damages, and such property was subject to the sole management and control of the husband. ${ }^{57}$ Because he could have alienated or encumbered this property, it passed to his trustee under section 70a(5) as property which he could "by any means have transferred." One exception to this may have been community real property which, although under the sole management and control of the husband, could not have been transferred without written consent of the wife. ${ }^{59}$ It has never been settled whether the husband's management and control of the commumity real property requires that it pass to his trustee; however, the fact that community realty was property which might have been levied upon and sold under judicial sale ${ }^{60}$ clearly compelled that the realty pass to the trustee under the express language of section $70 \mathrm{a}(5)$ of the Act. ${ }^{01}$ Therefore, prior to the 1975 amendments to the community property laws, the husband's trustee in bankruptcy was vested with title to his separate property and all community property subject to levy and sale by his creditors. ${ }^{62}$ This excluded only the wife's separate property and her uncommingled earnings and personal injury damages.

Prior to 1975 , a petition in bankruptcy could have been filed by or

57. See text accompanying notes 24-34 supra. It is only "title of the bankrupt" which vests in the trustee under Bankruptcy Act $\$ 70 \mathrm{a}, 11$ U.S.C. $\$ 110(a)(1970)$.

58. See text accoinpanying note 52 supra.

59. See text accompanying note 26 supra.

60. Grolemund v. Cafferata, 17 Cal. 2d 679, 684, 111 P.2d 641, 644, cert. denied, 314 U.S. 612 (1941).

61. Thus, while the husband's management and control (at least if unimpaired by a requirement of the wife's consent) is sufficient to vest his trustee with title to community property, it is not necessary in all cases; the "second prong" of section 70a(5) affords an equally sufficient alternative basis. 4A CoLLIER ON BANKRUPTCY II 70.15 at 137-42 (14 ed. 1975). The Ninth Circuit, in the recent case of Wikes v. Smith, 465 F.2d 1142 (9th Cir. 1972), acknowledged as much by abandoning the emphasis placed on management and control by the court in Hannah. 465 F.2d at 1144. Wikes did not change the substantive law in any way. When Wikes was decided the husband had full title to the community property; the wife was vested for tax purposes only. See text accompanying notes 33,34 supra.

62. A petition by a bankrupt did not pass community property under the sole management and control of the non-bankrupt or the non-bankrupt's separate property to the trustee because the bankrupt had no title to such property. See text accompanying notes 34, 35 supra and note 57 supra. To acquire such property for the estate, the trustee could have proceeded under Bankruptcy Act $\$ 70$ c, 11 U.S.C. $\$ 110$ (c) (1970), at least insofar as there were necessity claims proved in the estate. Pacific Finance Corp. v. Edwards, 304 F.2d 224 (9th Cir. 1962). For a more complete discussion of the problems presented by Pacific Finance see note 258 infra. It should be noted that unless the Pacific Finance doctrine is embraced, a petition by one spouse would pass all the separate property of the non-bankrupt spouse to the trustee, in his capacity as a hypothetical necessity creditor. But see, Medical Finance Ass'n v. Allum, 22 Cal. App. 2d (Supp.) 747, 752, 66 P.2d 761, 763 (Super. Ct. 1937), which held that nccessity debts would be construed to be joint and several debts of both spouses. 
against the wife as well as the husband. ${ }^{63}$ Such an event vested the trustee with title to the wife's separate property and any community property subject to her management and control, such as her uncommingled earnings and personal injury damages. Because the wife had no title to the other community property ${ }^{64}$ and any imterest she had in it could neither be transferred by her nor levied upon by her creditors, the community property under the management and control of the husband was not included in her bankruptcy estate. ${ }^{65}$ Thus, in Smedberg $v$. Bevilockway, ${ }^{66}$ the court held that the trustee, who was seeking half the commumity assets, had no better title or right in property than the bankrupt herself, and, therefore, did not succeed to any portion of the community property. ${ }^{67}$ Smedberg was subsequently applied in a bankruptcy context in In re Cummings. ${ }^{88}$

\section{II \\ The New California Community Property Law}

\section{A. The Interests of the Spouses}

The new community property law ${ }^{69}$ provides equal managerial rights for the husband and the wife in their community property. In the language of Civil Code section 5125,70 "either spouse has the management and control of the comnunity personal property," 71 whether acquired before or after January $1,1975 .^{72}$ Neither spouse may make a gift or other disposition of community personal property without valuable consideration. ${ }^{73}$ The conmunity real property is also under the

63. Bankruptcy Act § 4a, 11 U.S.C. \$ 22(a) (1970); In re Lyons, I5 F. Cas. 1192 (No. 8,469) (D. Cal. 1874).

64. See text accompanying notes 24-34 and note 57 supra.

65. See text accompanying notes $47-51$ and note 35 supra.

66. 7 Cal. App. 2d 578, 46 P.2d 820 (1st Dist. 1935). See note 114 infra.

67. Id. at 582,46 P.2d at 822 .

68. 84 F. Supp. 65, 68 (S.D. Cal. 1949). See Russel v. Laugharn, 20 F.2d 95 (9th Cir. 1927).

69. See note 4 supra.

70. Cal. Crv. Code $\$ 5125$ (a) (West Supp. 1975).

71. The meaning of this phrase can only be the subject of speculation until the courts have spoken on the matter. Does it imply that both spouses must agree to all transactions? Probably not, for one would assume that the legislature would have used the words "joint management and control" to compel such an imterpretation. Under the language as it now appears, one spouse may act without the consent of the other spouse in all dealings with the personal property. The desirability of this situation and the problems it entails will undoubtedly provide a fruitful topic for commentators. See, e.g., Kahn and Frinmer, supra note 4, at 518-19; Reppy, supra note 1, at 1007-25. However, these considerations are beyond the scope of this Comment.

72. The constitutionality of retroactive application of community property laws is thorouglily discussed in Reppy, supra note 1.

73. CAL. CTv. CODE $\S 5125$ (b) (West Supp. 1975). 
management and control of "either spouse" with the limitation that both spouses must join in any instrument by which community realty is transferred or encumbered. ${ }^{74}$ Separate property, both real and personal, remains under the sole management and control of its owner. ${ }^{75}$

A significant exception to the general policy of equal management and control is Civil Code section 5125 (d), ${ }^{70}$ which states that a spouse operating or managing a business or an interest in a business which is community personal property has the sole management and control of that business or interest. Thus, a married sole proprietor or general partner may run the business free from intervention by the other spouse. ${ }^{77}$ However, the entrepreneurial spouse is required to manage the community property business (as well as other community property) in good faith with respect to the other spouse. ${ }^{78}$

Under the new law, all commumity property, as well as the separate property of the contracting spouse, is obligated for the contracts of either spouse made after marriage. ${ }^{70}$ This is consistent with the concept that manageinent and control resides in both spouses. ${ }^{80}$ The separate property and earnings during marriage of one spouse are exempt from hability for debts of the other spouse which were contracted before marriage. ${ }^{81}$ Broader hability is imposed where debts are imcurred for

74. CAL. Crv. CoDe $\$ 5127$ (West Supp. 1975). This rule similarly applies to real property acquired before enactment of the nev community property law, and in fact amounts to joint management of community realty.

75. CaL. CTv. CODE $\$ \S 5107-08$ (West 1970).

76. CaL. Crv. CoDE $\$ 5125$ (d) (West Supp. 1975).

77. Legislative concern regarding intermeddling by the non-business spouse lead to this exception from equal management and control of the community property. See Transcript of Hearings Before the Jomt Interim Committee on Judiciary on Community Property, Sept. 25-26, 1972 Monterey, Calif., Oct. 10, 1972 San Francisco, Calif., Oct. 20, 1972 San Diego, Calif. at 5-6, 8, 30, 76,93. Under the prior law, the husband was entitled to manage the community property business of the wife; now neither spouse may interfere with the community property business of the other. See Gray v. Perlis, $76 \mathrm{Cal}$. App. 511, 245 P. 221 (1st Dist. 1926) and text accompanying notes 35, 36 supra.

78. CaL. Civ. Code $\$ 5125$ (e) (West Supp. 1975).

79. CAL. CTv. CODE \& 5116 (West Supp. 1975).

80. See note 44 supra. Sce Van Maren v. Johnson, 15 Cal. 308, 311 (1860).

81. CaI. CTV. Code $\$ 5120$ (West Supp. 1975). Prior to enactment of the new community property law, it was "settled" law in California that "[w]ith the one exception of the husband's earnings, the community property was liable for debts of the wife contracted before marriage." 7 B. WITKIN, SUMMaRY of CaLIFornia LAW Comminity Property $\$ 86$ (8th ed. 1974). However, the reasoning behind this result is not straightforward and the meaning of the statement itself is by no means clear. At common law, "[w] hen a man takes to himself a wife, he takes her for better or for worse and with her debts and encumbrances. . . . If the wife is indebted before marriage, the husband is bound afterwards to pay the debt, for he has adopted her and her encumbrances together." Johnson v. Taylor, 120 Cal. App. (Supp.) 771, 772, 4 P.2d 999, 1000 (Super. Ct. 1931). This liability of the husband for debts ineurred by the wife before coverture extended to both contract and tort obligations. 1 JONES' BrACKSTONE $630 \mathrm{n} .16$ (1915). Former CAL. CTv. CODE $\$ 5120$, which exempted the husband's separate property and 
necessities of life. Creditors providing such necessities are entitled to resort both to the community property and to the separate property of

wages from his otherwise full responsibility for the wife's prenuptial debts, was thus in derogation of the common law. It is clear that the exemption applied to contract claims. Vlautin v. Bumpus, 35 Cal. 214 (1868); Van Maren v. Johnson, 15 Cal. 308 (1860); Medical Finance Ass'n v. Allum, 22 Cal. App. 2d (Supp.) 747, 66 P.2d 761 (Super. Ct. 1937); White v. Gobey, 130 Cal. App. (Supp.) 789, 19 P.2d 876 (Super. Ct. 1933); Johnson v. Taylor, 120 Cal. App. (Supp.) 771, 4 P.2d 999 (Super. Ct. 1931). However, no California case has considered the statute's applicability to prenuptial tort creditors, and the common usage of the word "contracted" would imply that the exemption did not apply. Hence, the liability of the husband for prenuptial torts of the wife was seemingly unsettled before the new community property law' was passed. Clearly, the husband was not liable for postnuptial torts. Former CAL. CIV. CoDE $\$ 5122$ (West 1970), as amended, CAL. Civ. CoDE $\$ 5122$ (West Supp. 1975); McClain v. Tufts, 83 Cal. App. 2d 140, 187 P.2d 818 (2d Dist. 1947). But apparently no statute did away with the common law rule that the husband was liable for prenuptial torts of the wife. But cf. Hansen v. Cramer, 39 Cal. 2d 321, 326, 245 P.2d 1059 (1952) (Schaver, J., concurring) (noting possible applicability of former CAL. Crv. CoDE $\$ 170$ (now $\$ 5120$ ) to a tort situation). Therefore, the husband's separate property, his wages, the community property, and the wife's separate property could have been held liable for the prenuptial torts of the wife. As for the husband's creditors, the prior law made no distinction between tort and contract creditors whether prenuptial or not. This result followed from the husband's power of assignment over both his separate and community property. Van Maren v. Jolinson, $15 \mathrm{Cal}$. 308, 311 (1860). See cases cited in note 43, and see note 44 supra.

The legislative drafting of Civil Code section 5120 for the new community property law leaves much to be desired. The drafters simply substituted "spouse" where the former statute referred to husband and "other spouse" where the former statute read wife. Former CAI. CIv. CODE $\$ 5120$ (West 1970) states: "Neither the separate property of the husband nor his earnings after marriage is liable for the debts of the wife contracted before the marriage." The new community property law, CAL. CIV. Code $\S 5120$ (West Supp. 1975) states: "Neither the separate property of a spouse nor the earnings of the spouse after marriage is liable for the debts of the other spouse contracted before marriage." Such a drastic change cannot be made in a statute which is in derogation of a common law doctrine relating to coverture. In equalizing the statute with respect to sex, the legislature exempted certain property from liability without establishing primary liability for the debt. Two solutions for this dilennma may be suggested.

Since the husband's promise to pay for the wife's debts was a necessary feature of coverture, whereupon marriage the wife ceased to be a legal person separate from the husband, one possible approach under the new law would be to continue the legal fiction that the marriage vow is a pledge to pay the debts of the other spouse existing at the time of marriage. CAL. Crv. CODE $\$ 5120$ (West Supp. 1975) would then exempt separate property and wages of the non-debtor spouse. The result would be that prenuptial contract creditors could reach all the separate property of the debtor spouse and all the community property except the other spouse's wages, while prenuptial tort creditors would be able to reach all the separate property of both spouses and all the community property, including the business of the other spouse. Such liability, however, would seem to create an unwarranted preference for prenuptial tort creditors over all other creditors. No rationale can explain giving the prenuptial tort creditors more expansive rights than their postuuptial counterparts. To the contrary, because marriage is a windfall for prenuptial tort creditors it would be justifiable for them to reach less property than their postnuptial counterparts.

The preferable approach appears to be the one which the court in Van Maren v. Johnson, 15 Cal. 308, 311 (1860), used to establish hability of the community property 
each spouse. ${ }^{82}$ With respect to tort claims, a distinction is made between torts committed while performing an activity beneficial to the marital community and those committed under other circumstances. In the former instance, the liability must be satisfied first from the community property and then from the separate property of the spouse who committed the tort. In the latter, the separate property of the tortfeasor must be exhausted before the community property is liable. ${ }^{83}$ Thus, the previous California view that debts are attributed to either the husband or the wife is continued under the new community property law, ${ }^{84}$ because community property is liable for either spouse's contract obligations, whether or not they were incurred for the benefit of the community. ${ }^{85}$ Furthermore, a spouse's torts may subject both separate and community assets to liability. ${ }^{86}$

\section{B. Implications of the New Community Property Law}

\section{Marshaling Assets}

Marshaling assets is an equitable doctrine requiring that a debtor's assets be applied so as to protect a creditor or other person liaving an interest in only a portion of such assets. This doctrine is codified in Civil Code section 3433:

Where a creditor is entitled to resort to each of several funds for the satisfaction of his claim, and another person has an interest in, or is entitled as a creditor to resort to some, but not all of them, the latter may require the former to seek satisfaction from those funds to which the latter has no such claim, so far as it can be done without impairing the right of the former to complete satisfaction, and without doing injustice to third parties. ${ }^{87}$

This statute embodies the common law notion that nuarshaling nuay not be invoked if to do so would impair the rights of levying creditors, but extends the common law by allowing any person having an interest in

for the husband's prenuptial debts under the prior community property law. Because each spouse now has the power of assignment over all community property except the other spouse's business, this property should be liable for a spouse's prenuptial debts, with CaL. Crv. CoDe $\$ 5120$ (West Supp. 1975) exempting the other spouse's uncommimgled wages from liability for a spouse's prenuptial contract debts. This result avoids the huge preference given prenuptial tort creditors under the "marriage vow" approach, and the fact that the prenuptial creditors may reach slightly less community property than the postnuptial creditors is consistent with the windfall nature of the increase of their debtor's estate.

82. Cax. Crv. CODE $\$ 5121$ (West Supp. 1975).

83. CAL. CTV. CODE \& 5122(b) (West Supp. 1975).

84. See text accompanying notes $37-41$ supra.

85. CAL. CTV. CODE $\$ 5116$ (West Supp. 1975).

86. CAL. CIV. CODE \& 5122(b) (West Supp. 1975).

87. Car. CTv. Code $\S 3433$ (West 1970). 
the property to request marshaling. ${ }^{88}$ As applied in the context of a community property system, the doctrine would require that contractual claims incurred in a spouse's separate capacity be satisfied first out of that spouse's separate property, while contractual claims incurred for the benefit of the community would be satisfied first from community assets. ${ }^{80}$ Such a procedure should be adopted under the new community property law.

A distinction between separate and community property is already drawn in connection with tort liabilities, ${ }^{00}$ so that adoption of the doctrine for contractual debts would not be a large step. The task of distinguishing between community and separate contracts should be far easier than the determination of the cliaracter of tortious conduct, since contracts generally result from more planned and deliberate transactions. Therefore, no intolerable administrative burden on the courts would result from extending marshaling in this fashion. Furthermore, because equitable considerations strongly suggest that the assets enriched be held principally liable, marshaling seems particularly appropriate with regard to contractual claims, which will generally be traceable to a benefit conferred either upon the community property or upon the separate estate of one spouse. ${ }^{01}$

88. At common law, only creditors could request marshalimg of assets. 53 AM. JUR. 2d Marshaling Assets $\$ 9$ (1970).

89. Marshaling must be distinguished from the Washington system of separate and community debts, supra note 38. Under the Washington system, community property is not liable for separate claims. Marshaling presents no such barrier to separate creditors; rather, it is an equitable doctrine allowing the most appropriate asset to be exhausted before other assets are reached by creditors.

90. Cal. Civ. Code $\S 5122$ (b) (West Supp. 1975). Cal. Civ. Code $\S 5132$ (West Supp. 1975) also provides for marshaling of community assets before separate assets may be reached. See Reppy, supra note 1, at 1033 n.174.

91. The states of Texas, Arizona, and New Mexico marshal community and separate assets. See TeX. Fam. CODE $\$ 5.62$ (1975); ArIz. Rev. Stat. \$ 25-215(d) (Supp. 1973); N.M. STaT. §§ 57-4A-4, 57-4A-5 (Interim Supp. 1975). In Washington, the separate debts may only be satisfied from separate property. See note 38 supra.

In California, prior to passage of the new community property law, if the husband used commumity funds to improve his separate estate or to pay debts incurred during activities not benefiting the community, the wife had a right of reimbursement for her share of the community property. Weimberg v. Weinberg, 67 Cal. 2d 557, 563, 432 P.2d 709, 712, 63 Cal. Rptr. 13, 16 (1967). When the community funds were exhausted, voluntary payment by a spouse did not create reimbursement rights. See v. See, $64 \mathrm{Cal}$. 2d 778, 785, 415 P.2d 776, 781, 51 Cal. Rptr. 888, 893 (1966). The court in Beam v. Bank of America, 6 Cal. 3d 12, 23, 490 P.2d 257, 265, 98 Cal. Rptr. 137, 145 (1971), seemed to limit this doctrine to conscious choices made by a spouse. If a spouse is to be given a right of reimbursement in situatious like that in Weinberg, where communiy funds are spent on separate activities, it would seem judicially expedient to require the levying creditor to first resort to separate funds. In cases involving the opposite situation from See and Beam-an involuntary seizure of separate funds where the community property is not exhausted-it would seem that a right of reimburseinent would also exist. If so, marshaling in the first instance would be appropriate. 
The applicability of Civil Code section 3433 to creditors' remedies in a community property context has never been directly considered by the California courts; ${ }^{92}$ however, language in two leading cases dealing with the liability of community property suggests that marshaling was not permitted under prior law, although even this conclusion is by no means clear. In Spreckles v. Spreckles, ${ }^{03}$ the court stated:

If suit were brought upon a liability incurred in a business, the profits of which would be community property, and judgment recovered, execution could be levied upon the separate estate of the husband, and the debt entirely satisfied therefrom. His separate estate, during the entire marriage, is liable to be taken for community debts, and of course furnishes a credit in aid of community business. If the community loses, the loss may fall upon his separate estate, but his separate estate cannot profit by the success of the community. ${ }^{94}$

These views were later repeated in Grolemund $v$. Cafferata, ${ }^{95}$ in which the court observed that "the creditor of the husband could, at his option, sell under execution either the husband's separate property or the community property." ${ }^{\prime \prime 6}$ Strictly speaking, these remarks must be considered dicta insofar as the court was not confronted in either case with the question whether marshaling was appropriate. Furthermore, the conditional phrasing of the remarks in Spreckles might indicate that the court was not foreclosing the possibility of marshaling, in which case such a preclusive intent should not be imputed to the court in Grolemund, which by its language purported only to paraphrase Spreckles. ${ }^{77}$ The doctrine of marshaling begins with the premise that all the property under consideration could be sold in satisfaction of the debt (the point the court in Spreckles was addressing), then proceeds to determine which property should be sold. Neither court addressed the primary and secondary liabilities of the marital property.

Even if Spreckels and Grolemund could be read so broadly as to preclude marshaling of assets under prior law, a similar result does not

If they are debts incurred in behalf of the community manifestly the community ought to contribute toward their payment. It will be time enough to decide what ought to be the rule with respect to debts incurred by the husband before marriage or on his separate account when a case is presented which clearly involves them.

Estate of Haselbud, 26 Cal. App. 2d 375, 383, 79 P.2d 443, 448 (4th Dist. 1938).

92. The court in Van Maren v. Johnson, 15 Cal. 308 (1860) (decided before the 1872 enactmeut of CTV. CoDe $\S 3433$ (West 1970) held that a judgment on a prenuptial contract debt of the wife could be enforced "indiscriminately" against the separate property of the wife or the community property. Id. at 313 .

93. 116 Cal. 339, 48 P. 228 (1897).

94. Id. at 343,48 P. at 229.

95. 17 Cal. 2d 679, 111 P.2d 641, cert. denied, 314 U.S. 612 (1941).

96. Id. at 682, 111 P.2d at 643 .

97. Id. 
necessarily follow under the new community property law. Civil Code section 3433 requires that the party requesting marshaling have an "interest" in the fund sought to be preserved. It is arguable that prior to 1975 , the wife did not have a sufficient interest in the community property to justify marshaling the husband's separate property for her benefit. Under the Spreckels decision the wife enjoyed a "mere expectancy" in the community property. ${ }^{98}$ By the time Grolemund was decided, her interest was "vested," but only for tax purposes. ${ }^{99}$ If inarshaling is still to be denied, the rationale can no longer be the deficiency of the wife's interest, since the rights of the spouses in the community property (including the right of managenent and control) are equal under the new community property law.

It is arguable that the failure to include a specific marshaling provision in section $5116^{100}$ (contract debts) while providing for nuarshaling in section 5122 (b) ${ }^{101}$ (tort debts) indicates a legislative intent not to require marshaling of assets in contract situations. However, it is unlikely that such a requirement was fully discussed by the legislature, ${ }^{102}$ particularly in view of the oversights in the provisions dealing with prenuptial tort debts. ${ }^{103}$ Furthermore, the inarshaling requirenent contained in section 5122 (b) is much stronger than would be imposed under section 3433. Section 5122(b) requires that a creditor exhaust one form of property before proceeding against the less appropriate type of asset. Marshaling, under section 3433, may not impose such a burden on the levying creditor. Only where the community and separate assets are equally accessible should marshaling be invoked. In other cases, the non-debtor spouse is given a right of reimbursenent. ${ }^{104}$ In order to avoid placing any burden on the creditor, it would be wise for the spouse requesting narshaling to intervene in the action against the obligor spouse and request that the court include marshaling instructions in its judgment. If this is done, it seenis reasonable to suggest that contractual debts incurred during activities not benefiting the community be satisfied first froin separate property and that debts incurred for

98. See text accompanying note 24 supra.

99. See text accompanying note 34 supra.

100. Cal. Civ. Code $\$ 5116$ (West Supp. 1975).

101. CaL. Crv. CoDe $\$$ 5122(b) (West Supp. 1975).

102. The marshaling of assets included in CAL. CTv. CODE $\S 5122(\mathrm{~b})$ (West Supp. 1975) evolved through a series of proposed bills. Comment, Tort Debts Versus Contract Debts: Liability of the Community Under California's New Community Property Law, 26 HAST. L.J. 1575, 1588-91 (1975). There is no indication that Car. Crv. CoDE $\S 5116$ (West Supp. 1975) received this scrutiny.

103. See note 81 supra. It would seem incongruous to marshal postnuptial tort debts and not prenuptial tort debts.

104. See note 91 supra. 
the benefit of the community be satisfied first from community assets. ${ }^{105}$ Since inarshaling may not be applied to the prejudice of the levying creditor, the unsatisfied portion of any claim would be satisfied out of the remaining category of assets.

\section{Creditors' Remedies and the Business of the Spouse \\ a. Statutory Interpretation}

The rights of creditors of one spouse against a business or a business interest under the sole management and control of the other spouse must be examined carefully. Since, under the new community property law, community property is liable for the postnuptial contract and tort obligations of either spouse, ${ }^{106}$ a business which is community property would seen1 to be liable for the obligations of the non-business spouse. However, the preamble to the 1974 amendments to the new community property law declares that "the liability of community property for the debts of the spouses has been coextensive with the right to manage and control community property and should remain so."107 Since the new community property law expressly provides that a community property business is subject to the sole management and control of the spouse actually operating it, ${ }^{108}$ the preamble would seen to

105. "Whether or not there is any specific statutory cleclaration that community obligations chargeable against separate property must first be charged against community property, such a requirement constitutes a fundamental principle of commumity property." DEFUNAAK \& VAUGHN, supra note 11, at 420 . This result was also recognized under the Spanish law of community property. Id. at 378-89.

106. CAL. CTV. CODE $\S \S 5116,5122$ (b) (West Supp. 1975).

107. The Preamble provides:

The people of the State of California do enact as follows:

Sectron 1. The Legislature finds and declares that (1) the extension of the right to manage and control all of the community property of a marriage to both spouses entails important social and economic considerations, (2) the right to manage and control community property is not a fundamental right which may not be divested by the Legislature and is not accorded the same status as the rights of the spouses in community property during marriage which are, and remain, present, existing, and equal, and (3) the applieation of the right to manage and control community property to all community property of a marriage, whether acquired before or after January 1, 1975, is necessary to achieve social and economic equahty and facilitate commercial transactions.

The Legislature further finds and declares that (1) the liability of community property for the debts of the spouses bas been coextensive with the right to manage and control community property and should remain so, (2) the extension of the hability of community property for obligations contracted prior to January 1, 1975, does not impair the rights of creditors or the interests of the spouses in the community property, and (3) the extension of the liability of coinmunity property avoids undesirable preferences among creditors of the community.

Ch. 1206, § 1, [1974] Cal. Stat. - (emphasis added). [hereinafter cited as Preamble]. 108. Cal. Crv. Code $\$ 5125$ (d) (West Supp. 1975).

By analogy to the former law in California, it is arguable that the non-business 
indicate a legislative intent to immunize such a business from the creditors of the non-managing spouse. As a matter of statutory construction, however, it is improbable that this was the intent of the legislature.

The legislative declaration in the preamble must be read in context. It states that the extension of management and control to both spouses entails important social and economic considerations, that the right of management and control is not a fundamental interest, and that the retroactive application of management and control was necessary to achieve social and economic equality and to facilitate commercial transactions. ${ }^{109}$ These observations were made in anticipation of fifth amendment challenges relating to the retroactivity of the statute. ${ }^{110}$ In this context, the statement that the liability of community property for debts should remam coextensive with the rights to management and control is simply the legislative rationale for imposing retroactivity in the area of creditors' remedies; the preamble goes on to comment that retroactive application of the statute does not impair the rights of creditors. ${ }^{111}$ Thus, the preamble reflects a general legislative desire to extend the rights of the wife and her creditors; a literal interpretation which would limit the rights of creditors should not be followed at the expense of the broader goal. Moreover, such an interpretation would generate a conflict with the express and unambiguous statutory rule that the community property is liable for the obligations of both spouses. This is in itself a sufficient reason to presume that the preamble was not intended to deny creditors of the non-business spouse resort to the assets of a community property business. ${ }^{112}$

spouse would have no title to the community business but would be vested for tax purposes only. See text accompanying notes 33-34 supra. However, if such property is liable for debts of the non-business spouse, it is likely that a court would hold that the non-business spouse, though lacking management, has title to the business.

109. Preamble, supra note 107.

110. Reppy, supra note 1, at 1010. Such legislative preambles are often useful to forestall constitutional challenges by making a record of legislative policies. Nutting, The Uses of Preambles, 50 A.B.A.J. 493 (1964).

111. Further support for the statement that the preamble is directed only at the constitutional issues is that no other portion of the preamble is even arguably statutory in nature. Preamble, supra note 107.

112. The general rule is that in case of doubt as to the proper construction of a statute, resort must be had to the preamble for legislative intent, but where the statute is unambiguous, it is not controlled by the preamble. 82 C.J.S. Statutes $\$ 349$ (1953). The legislative intent may also be inferred from modification of the prior law made by the new community property law. Former CAL. Crv. CoDE $\$ 5122$ stated that a spouse's tort creditor could be satisfied out of community property over which that spouse had management and control but not out of other community property. This restriction was eliminated under the new law which now renders the community property liable without regard to questions of management and control, thus indicating a legislative intent that all types of community property be susceptible to the claims of both spouses' creditors. CAL. Crv. CODE \& 5122(b) (West Supp. 1975). 
Allowing creditors of the non-business spouse some access to the assets of a community property business managed by the other spouse is sound policy. There is no compelling reason why an uncompensated tort or contract creditor should go unsatisfied because the community business, possibly with a large capital surplus, is managed by the other spouse. However, in allowing access to the other spouse's community property business, the judiciary must be careful to avoid offending another policy of the new community property law: protection of the business spouse from intermeddling by the non-business spouse in the affairs of the community property business. ${ }^{113}$ Allowing creditors of the non-business spouse to levy on assets of the other spouse's business would disrupt a going concern, and even the threat of such interference could prevent the business from obtaining essential unsecured credit. Fortunately, the fact that the busimess is liable for the debts of the nonbusiness spouse does not render its assets subject to levy by writ of execution and judicial sale in satisfaction of those debts. This follows from the general rule that an interest must be assignable or transferrable to be subject to levy under a writ of execution. ${ }^{114}$ Since the business spouse has sole management and control of the business, the assets of the business may not be transferred by the other spouse and are therefore not subject to levy and sale. This result is desirable in light of the policy of leaving the management and control with the business spouse, for it results in minimum interference with the operating business. A creditor of the non-busimess spouse can reach the business assets only by equitable proceedings in the nature of a creditor's bill ${ }^{115}$ or supplemen-

113. See note 77 supra and CAL. CTv. Code $\$ 5125$ (d) (West Supp. 1975).

114. The court in Howell v. Foster, 65 Cal. 169, 3 P. 647 (1884), when discussing the problem of levy and sale, stated:

It is a fundamental principle ... that an attaching creditor can acquire no greater right in attached property than the defendant had at the time of the attachment. If, therefore, the property be in such a situation that the defendant has lost his power over it, or has not yet acquired such interest in or power over it as to permit him to dispose of it adversely to others, it cannot be attached for his debt.

1d. at 173, 3 P. at 649, quoting Drake on ATTACHMENTs $\$ 245$ (6th ed. 1884). Thus transferability or assignability is necessary for attachment or execution under California law. This is also the general rule. 30 AM. JUR. 2d Executions $\$ 147$ (1967). Furthermore, in Smedburg v. Bevilockway, 7 Cal. App. 2d 578, 46 P.2d 820 (1st Dist. 1935), the court held that community property under the sole manageinent and control of one spouse could not be transferred by the non-managing spouse by any means nor levied upon by her creditors. "Under the laws of California, except to her husband, a wife may not convey her interest in the community property. As she may not dispose of her interest the same is not subject to attachment. Nor is it subject to sale under a writ of execution." Id. at 582, 46 P.2d at 822 (citations omitted). Thus, while liability is necessary to subject property to execution, it is not sufficient. The property must be transferrable by the debtor before it may be subject to levy and sale unless a special statutory exception is created. See, e.g., CaL. Code Civ. Pro. \& 688.1 (West 1970).

115. 5 B. Witkin, California Procedure \& 143 at 3506-07 (2d ed. 1971); Smith v. Smith, 51 Cal. App. 2d 29 (1st Dist. 1942). 
tal proceedings. ${ }^{116}$ If, in the course of such proceedings, it became clear that non-business community assets were available, the court would almost certainly require the creditor to resort to these assets before proceeding against assets productively employed in a community property business.

\section{b. The Extent of Business Asset Liability}

Assuming that the only assets available to satisfy the claims of creditors of the non-business spouse belong to the community property business of the other spouse, to what extent may these creditors reach the assets? If the business is a partnership, the result is clear: the nonbusiness spouse's creditors may reach only the business spouse's partnership interest, which consists of the business spouse partner's pro rata portion of the excess of partnership assets over partnership liabilities. ${ }^{117}$ Thus, the non-business spouse's creditors have the same rights as the individual creditors of the partner spouse. Neither class of creditors is capable of disrupting the partnership by resorting directly to partnership assets; this course may only be pursued by the partnership's own creditors. ${ }^{118}$

More troublesoine considerations are raised where the community property business is a sole proprietorship. Prior to enactment of the new community property law, the sole proprietorship was exposed to claims of the business spouse's individual and business creditors alike; ${ }^{: 11}$ no priority was accorded the business creditor. It is tempting to assume that the non-business spouse's creditors should likewise have complete access to the business assets, but analysis indicates that such a result is questionable.

Unrestricted liability of the sole proprietorship to the non-business spouse's creditors is desirable insofar as it treats the individual creditors of both spouses equally. It is also consonant with the notion that no community assets should be withheld as long as the creditors of either spouse remain unsatisfied. On the other hand, subjecting business assets to the claims of the non-business spouse's creditors could result in the busmess spouse being forced to satisfy business debts out of separate

116. Cal. Code Ctv. Pro. $\S \S 714-23$ (West 1955); 5 B. Witktn, Caltfornta ProCEDURE $\$$ 123-27 at 3487-92 (2d ed. 1971); E. JACKSON, CALIFORNIA DEBT Collection PrACTICE $\$ 18$ at $417-58$ (1968).

117. This would be done by the equitable equivalent of a charging order in supplemental proceedings. See CAL. CORP. CODE $\$ 15028$ (West 1955); J. CraNe \& A. BOMBERG, LAW OF PARTNERshIP $\S 43$ at $246-49$ (1968). For a discussion of the remedies available in supplemental proceedings, see text accompanying notes 126-29 infra.

118. CAL. CoRP. CODE $\$ 15025$ (2) (c) (West 1955).

119. H. HENN, LAW OF CoRporations $\$ 18$ at $43-46$ (2d ed. 1970). 
property. ${ }^{120}$ This seems particularly unfair if, as is likely, the business debts are substantial. In such cases, the business spouse's separate property would be, in effect, appropriated for the benefit of the other spouse's creditors-an incongruous result. Another unsalutory effect of unrestricted liability is the probability that business creditors will be less inclined to extend unsecured credit in reliance on business assets if those assets were completely available to satisfy creditors of the other spouse. The major concern, however, is the possible disruption of the business by the creditors of the non-business spouse that could result from liquidating essential business assets or draning operating capital. Some accomodation should be reached between the conflicting policies of the community property law, which seek to grant creditors access to the community assets while shielding the community property business of one spouse froni interference by the other.

One method of accomodating the policies of the new law would be to accord the community property sole proprietorship limited partnership treatment vis-à-vis the creditors of the non-business spouse, thus subrogating their claims to those of the business creditors. ${ }^{121}$ Indeed, the analogy is quite close. The non-business spouse, as a counterpart of the limited partner, has an ownership interest under the new community property law, but lacks powers of management and control. ${ }^{122}$ That spouse also has control over proceeds distributed by the business and receives a pro rata share of the business on dissolution of the marriage. ${ }^{123}$ However, the individual creditors of the non-business spouse should not be limited to a pro rata share of the assets, as creditors of a limited partner would be; ${ }^{124}$ rather, they should be able to reach the

120. Admittedly, all creditors' actions against the community property prejudice the other spouse's separate property, though marshaling and reimbursement may minimize this impact. See text accompanying notes 87-105 supra. However, outside the business context this effect is likely to be minor, for the amount of unsecured debt held by the business spouse in an individual capacity is likely to be small. But in the business context, substantial amounts of unsecured debt may be attributable to the spouse; the spouse's separate property should not bear this burden.

121. Such a subrogation of individual creditors to the rights of business creditors existed in equity prior to the enactment of the Uniform Partnership Act and the Uniform Limited Partnership Act. J. Crane aNd A. Bromberg, LAw of Partnerships $\S$ 43 at 241-44 (1968). The rule as it developed in equity rested on the rationale that because there were several participants in the partnership, fairness demanded that an individual's separate creditors not be allowed to take the assets of the partnership, leaving the other partner's separate estates to satisfy the partnership debts. Id. at 242 . This reasoning is also applicable to the community property system. It would be inequitable for the non-business spouse to reach the business assets and leave the managing spouse holding all the debts of the business but none of the assets.

122. Compare CaL. Corp. CODE $\$ 15507$ (West Supp. 1975), with CaL. Civ. Code $\S 5125(\mathrm{~d})$ (West Supp. 1975).

123. CAL. Crv. CoDe $\$ 4800$ (West Supp. 1975).

124. CAL. CORP. CODE $\$ 15522$ (West 1955). 
entire "community interest" in the business. ${ }^{125}$ Therefore, in supplemental proceedings, ${ }^{128}$ a judgment creditor of the non-business spouse should be able to obtain an order applying the "community interest" of the busmess toward satisfaction of the debt. ${ }^{127}$ In addition, since by hypothesis the business remains a going concern, ${ }^{128}$ the judgment creditor should be allowed to reach a portion of the future profits of the business. This could be accomplished either by agreement with the business spouse or by appointment of a receiver for profits until such time as the claim is satisfied. ${ }^{129}$

The creditors of the business spouse, however, should not be limited to the "community interest" of the business. There is no compelling analogy to partnership law that would subrogate non-business claims to business debts, ${ }^{130}$ and no intent to change the law of creditors' remedies vis-à-vis sole proprietorships can be found in the community property law. ${ }^{131}$ While it might be argued that limiting the entrepreneur's non-busmess creditors to the "community interest" in the business

125. The "community interest" available to the creditors of the non-business spouse's creditors could be defined as the excess of the assets over the liabilities of the business; however, to impair the capital of a business to this extent by placing it on the brink of insolvency is inconsistent with the concept of minimum intervention with the business. Rather, the court should determine, in its discretion, how much equity the business requires to function effectively, while recognizing that continuance of the business offers the best hope for eventual satisfaction of all claims. Because continuation of the business is in the best interest of all parties, only that portion of the excess of assets over liabilities which can be removed from the business without harming the business should be available to creditors, with a provision for a charging order against a portion of the subsequent profits. This amount is hereinafter termed the "community interest" in the business.

126. CaL. CODE CIv. Pro. \$\$ 714-23 (West 1967 and West Supp. 1975).

127. Cal. Code Crv. Pro. $\$ 719$ (West 1967). This assumes that the debtor has sufficient title in this property. See note 108 supra. It is likely that if the business is found to be liable for such claims that a court would also hold that the debtor had sufficient title in the business to allow his or her creditors to use supplemental proceedings to reach the assets. The business spouse would be brought into such proceedings under CAL. Code Ctv. Pro. \$ 720 (West 1967).

128. See note 125 supra. By definition, removal of the community interest from the business leaves the business as an ongoing, profit generating operation.

129. CAL. Code CTV. Pro. \$ 564(4) (West 1967) provides in part: "[A] receiver may be appointed . . . 4. After judgment . . . in proceedings in aid of execution, when au execution has been returned unsatisfied, or when the judgment debtor refuses to apply his property in satisfaction of the judgment . ..." Morand v. Superior Ct., 38 Cal. App. 3d 347, 113 Cal. Rptr. 281 (1st Dist. 1974). By analogy, see Car. Corp. Code $\S 15028$ (1) (West 1955) and 7 CAL. PRACTICE §§ 56:208-56:214 (1968).

130. See note 121 supra. If the business spouses's individual creditors levy and sell the business, the business debts are not forced against the other spouse's separate property, but remain liabilities of the business spouse.

131. To create such a rule would make the sole proprietorship an entity with the same protection for creditors as a partnership. Furthermore, creditors' remedies against unmarried sole proprietors would differ from those applicable against married sole pro. prietors. 
has the virtue of promoting equal treatment of the individual creditors of either spouse by "avoid[ing] undesirable preferences among creditors of the community,"132 this is more an argument of selnantics than of substance. The creditors of both spouses are treated equally insofar as each can reach the separate property of their debtor, that debtor's business, the community property, and the "community interest" in the other spouse's business. The fact that the size of these estates inay differ is not a preference between creditors of the spouses but a consequence of a community property system of marital landownership that allows the spouses to hold both separate and community assets. Finally, because business property is under the nuanagement and control of the business spouse, it may be levied upon directly without result to equitable proceedings. This being so, there is no opportunity for a court of equity to stay the levying creditor's hand.

To summarize, while the legislature has offered no guidelines defining the rights of creditors in a commumity property business, it has singled out such a business for special treatment. With regard to the non-business spouse's creditors, possible judicial approaches include holding the business: (1) not liable, in reliance on the preamble of the community property law; (2) fully liable in equitable proceedings, thereby permitting interference with a going concern; or (3) liable to the extent of the "community interest" in the business. Until the legislature acts to clarify the statute, allowing access to the "community interest" of the business seems to present a sound compromise between denying all resort to business assets and allowing full resort. ${ }^{133}$ With regard to the creditors of the business spouse, the court should hold the business fully hable.

\section{III \\ BANKRUPTCY AND THE NEW CALIFORNIA \\ COMMUNITY PROPERTY LAW}

\section{A. The Bankruptcy Petition}

The initial question under the new community property law is whether a spouse can individually file a voluntary petition in bankruptcy. Regardless of the judicial resolution of the question whether "inanageinent and control by either spouse" ineans joint inanagement and control or equal management and control, ${ }^{134}$ it is clear that under the

132. Preamble, supra note 107.

133. The result upon liquidation of a sole proprietorship should be to hold the business fully liable for the claims of both spouses' creditors. See text accompanying notes 197, 198 infra.

134. CaL. Crv. Code $\$ 5125$ (West Supp. 1975); id. $\$ 5127$ (West Supp. 1975). See text accompanying notes 69-75 supra. 
Bankruptcy Act "[a]ny person . . . shall be entitled to the benefits of this Act as a voluntary bankrupt." ${ }^{135}$ The bankrupt need only owe debts, no matter how small; he or she need not be insolvent. ${ }^{136}$ Furthermore, absent a showing of fraud, the motive of the bankrupt is immaterial. ${ }^{137}$ While it might be argued that a petition by only one spouse would violate the "good faith" management and control provision of the new community property law by enabling the petitioning spouse to exercise too much control over the community holdings, ${ }^{138}$ the supremacy clause of the United States Constitution ${ }^{139}$ undoubtedly ensures the right of each spouse to file a petition in bankruptcy notwithstanding the California law. Therefore, upon filing a petition, the spouse will be adjudicated a bankrupt by operation of law. ${ }^{140}$ The estate of the bankrupt then passes to his or her trustee.

If a spouse meets the requisite conditions, he or she may be adjudged an involuntary bankrupt under section $4 \mathrm{~b}$ of the Act.141 Professor Riesenfeld states that in addition to satisfying the requirements of section $4 \mathrm{~b}$, at least the following requirements must also be satisfied: ${ }^{142}$ (1) the bankrupt must owe provable debts of $\$ 1000$ or more; (2) the bankrupt must have committed one of the six enumerated acts of bankruptcy within 4 months prior to the petition; ;43 (3) the requisite number of creditors must join in the petition; (4) the bankrupt must have been properly served with the petition; and (5) the bankrupt must have defaulted or must have had an impartial trial (by jury, if requested) on the issues of the commission of the act of bankruptcy and insolvency. The only peculiarity posed by the community property system relates to the test for insolvency, which cannot be discussed until after a discussion of the estate of the bankrupt. ${ }^{144}$

135. Bankruptcy Act $\S 4 a, 11$ U.S.C. $\S 22$ (a) (1970). Bankruptcy Act $\S 59 a, 11$ U.S.C. $\$ 95(a)$ (1970) provides that "[a]ny qualified person may file a petition to be adjudged a voluntary bankrupt."

136. 1 COLLIER ON BANKRUPTCY $\Uparrow 4.03$ at 579 (14th ed. 1974).

137. Id. at 579-81.

138. CaL. Crv. Code $\$ 5125$ (e) (West Supp. 1975).

139. U.S. CoNST. art. VI, cl. 2.

140. Bankruptcy Act $\S 1(2), 11$ U.S.C. $\S 1(2)$ (1970); Bankruptcy Act $\S 18 f, 11$ U.S.C. $\$ 41(f)(1970)$.

141. 11 U.S.C. \$ 22(b) (1970).

142. S. RIesenfeld, Creditors' Remedies and Debtors' Protection 393-94 (1967).

143. Bankruptcy Act $\$ 3 a(5), 11$ U.S.C. $\$ 21(a)(5)$ (1970), which provides that "[a]cts of bankruptcy by a person shall consist of his having . . . (5) while insolvent or unable to pay his debts as they mature, procured, permitted, or suffered voluntarily or involuntarily the appointment of a receiver or trustee to take charge of his property," should be read broadly enough to include the situation where a petition by one spouse renders the other spouse insolvent. infra.

144. For a discussion of the insolvency test, see text accompanying notes 199-202 


\section{B. The Estate of the Bankrupt}

1. The Statutory Interaction Between Sections 70a(5) and 70c of the Bankruptcy Act and the California Community Property Law

As noted earlier, the estate of the bankrupt-the property which passes to the trustee-is governed by section 70a of the Bankruptcy Act. ${ }^{145}$ However, only subsection (5) is relevant to a discussion of the California community property law. This subsection automatically vests the trustee with the bankrupt's title to property so long as the bankrupt could have transferred such property by any means or his creditors could have reached the property by levy and judicial sale. Because all community personal property except the other spouse's business may be transferred by the bankrupt, it passes to the trustee upon adjudication of the bankrupt. ${ }^{146}$ Similarly, community realty passes to the trustee as property subject to levy and sale. ${ }^{147}$ The "community interest" in the business of the non-bankrupt spouse ${ }^{148}$ should also pass to the trustee under section $70 \mathrm{a}(5),{ }^{149}$ assuming that the bankrupt has title to such property. ${ }^{150}$ If it is held that the bankrupt does not have title to the "community interest" of the non-bankrupt spouse's business, the trustee may still avail himself of such property under section $70 \mathrm{c}$ of the Act, which provides: "The trustee shall have as of the date of bankruptcy the rights and powers of: (1) a creditor who obtamed a judgment against the bankrupt upon the date of bankruptcy, whether or not such creditor exists . . ."151 Under this section, the trustee enjoys the status of a creditor and thus inay reach the non-bankrupt spouse's busmess interests if this is permissible under state law. Under either section 70a(5) or

145. 11 U.S.C. $\$ 110$ (a) (1970).

146. CAL. Crv. CoDE $\S \S 5125$ (a), (d) (West Supp. 1975). See text accompanying notes $69-73,77,78$ supra. This assumes that the bankrupt has title to all the community assets. See text accompanying notes $162-70$ infra.

147. Cal. Crv. Code $\$ 5127$ (West Supp. 1975); Grolemund v. Cafferata, 17 Cal. 2d 679, 684, 111 P.2d 641, 643, cert. denied, 314 U.S. 612 (1941). See text accompanying notes 59-61 supra.

148. See note 125 supra and text accompanying notes 106-33 supra. This represents the assets available to the bankrupt's creditors under state law proceedings. See text accompanying notes 126-29 supra. Of course, if California courts hold that the entire business is liable for the claims of the non-business spouse's creditors, the entire business of the non-bankrupt would pass to the trustee. This is an undesirable result whicl could precipitate liarassment bankruptcies on the eve of divorce proceedings.

149. Although the business is not subject to levy and sale, see note 114 supra, the scope of Bankruptcy Act $\$ 70 \mathrm{a}(5)$ is sufficiently broad to encompass property which is liable only in supplemental proceedings, because it allows the trustee to acquire "property ... which might have been levied upon and sold under judicial process against [the bankrupt], or otherwise seized, impounded, or sequestered." 11 U.S.C. $\$ 110$ (a)(5) (1970). Carmona v. Robinson, 336 F.2d 518 (9tl Cir. 1964) (supplemental proceedimgs).

150. See notes 57,108 supra.

151. 11 U.S.C. $\$ 110(\mathrm{c})(1970)$. Also see text accompanying notes $162-70$ infra. 
section 70c, it would be incumbent upon the trustee to show that the other assets of the bankrupt's estate are not sufficient to pay the claims of the bankrupt's creditors and that as a representative of those creditors, the trustee should therefore be permitted access to the "community interest" of the non-bankrupt spouse's business. ${ }^{152}$

\section{The Impact on the Non-bankrupt Spouse and His or Her Creditors}

Section $70 \mathrm{a}(5)$, possibly in conjunction with section $70 \mathrm{c}$, passes the following property to the estate of the bankrupt: (1) the bankrupt's separate property, (2) the community property under the management and control of the bankrupt spouse, and (3) the business interest of the non-bankrupt spouse to the extent state law allows. This result may leave the creditors of the non-bankrupt spouse in an unenviable position. Must these creditors look only to the non-bankrupt spouse's separate property for satisfaction of their debts? If such property is not sufficient, must the creditors of the non-bankrupt spouse remain unsatisfied while the creditors of the spouse first to declare bankruptcy divide the community assets? The fair and equitable answers are clearly no..$^{153}$ Those creditors of either spouse who can reach the community property under state law prior to bankruptcy should share in the distribution of the estate in bankruptcy.

One ineans of preventing distribution of the community property among creditors of only one spouse would be to interpret the community property law such that no community property would pass to the trustee in bankruptcy upon the petition of one spouse. This argument was strongly urged in Hannah v. Swift $t^{154}$ following the 1927 change in the community property laws. The wife, contesting the result that all the

152. If there are sufficient non-business assets in the estate to pay creditors, the business of the other spouse should not be disturbed. See text accompanying notes 11529 supra. If the bankrupt is insolvent, the community interest in the business should then be established. Any receivership appointed under state law should be dissolved by the petition in bankruptcy. See text accompanying notes 126-29 supra. The trustee should use his avoiding powers to pursue any assets collected by the receiver; however, the trustee should not be able to collect profits from the business earned after the date of the petition. These are post-bankruptcy assets which are necessary to the fresh start of the bankrupt. See Local Loan Co. v. Hunt, 292 U.S. 234 (1934); Lines v. Fredrick, 400 U.S. 18 (1970); Segal v. Rochelle, 382 U.S. 375 (1966); Comment, Bankruptcy: The Disposition of the Debtor's Unliquidated Cause of Action for Personal Injuries, 63 CALIF. L. REv. 579 (1975).

153. "It would seem inconsistent both with bankruptcy principles and the local cominunity property system, if bankruptcy would grant the creditors of the husband a priority over those creditors of the wife who otherwise would be free to compete with the former in the access to certain components of the community estate." 1 CollreR ON BANERUPTCY If 1.19 at 116 n.72 (14th ed. 1974) (discussing necessity creditors of the wife in California prior to 1975 . See text accompanying note 46 supra.)

154. 61 F.2d 307 (9th Cir. 1932). 
community property was to pass to her husband's trustee, argued that the community property should be treated either like homesteaded property or as if it were a tenancy by the entirety. ${ }^{165}$ Both of these propositions are untenable when the Bankruptcy Act is read in conjunction with the California community property law. The analogy to homesteaded property is not strong. The honiestead is not a means of holding property; ${ }^{156}$ it is a means of exempting property from the reach of creditors. ${ }^{157}$ While homesteaded property (whether community or separate property) is similar to community real property in that it cannot be transferred without the consent of both spouses, it differs from community property in that it is exempt from the reach of creditors. This feature alone is sufficient to warrant a different treatment in bankruptcy. Treating the community property as if it were a tenancy by the entirety might also prevent it from passing to the trustee in bankruptcy. ${ }^{168}$ Under the tenancy by the entirety system, the husband and wife must join in all conveyances, and the property so held is liable only for the joint debts of the spouses. ${ }^{159}$ These facts dictate the result that a tenancy by the entirety does not pass to the trustee in bankruptcy without a petition by both spouses. ${ }^{160}$ However, under the California community property

155. Brief for Appellant at 48-52, 56-70, Hannah v. Swift, 61 F.2d 307 (9th Cir. 1932).

156. The Civil Code provides as follows:

The ownership of property by several persons together is either:

(1) Of joint interests

(2) Of partnership interests

(3) Of interests in cominon

(4) Of community interest of husband and wife.

CAL. Civ. Code $\$ 682$ (West 1970).

157. CaL. Civ. CoDe $\S \S 1237-69$ (West 1970); 25 CaL. Jur. 2d Homesteads $\S 1$ (1955).

158. There is unfortunate language in Sinedberg v. Bevilockway, 7 Cal. App. 2d 578, 46 P.2d 820 (1st Dist. 1935). In the face of Hannah v. Swift, 61 F.2d 307 (9th Cir. 1932), which passed all community property to the trustee in bankruptcy, the Smedberg court said:

Under the common law there existed what were known as estates by en-

tireties. They exist in several of our sister states. They have many characteristics in common with the estate in California which we call community property. A comparison shows they differ in only a few characteristics-no one of which is important so far as the rights and duties of a trustee in bankruptcy are concerned. However, it has been held that on the bankruptcy of one spouse his or her trustee in bankruptcy takes no title to an estate by the entirety. "Where the reason is the same, the rule should be the same."

7 Cal. App. $2 \mathrm{~d}$ at 583, 46 P.2d at 822 (citations omitted). On the facts of this case, the holding of the court was correct. However, what the court should have said was that because the wife had no title to the community property, it did not pass to the trustee in bankruptcy. See text accounpanying notes 64,65 supra. The court may have erroneously believed that where the rule was the same, the reason inust be the sane.

159. For a discussion of the tenancy by the entirety system and its relation to bankruptcy, see 4A ColliER on BANKRUPTCY, If 70.17 at 180-90 (14th ed. 1974).

160. Id. 
system, creditors of either spouse may reach the community assets, thus mandating a different result. ${ }^{161}$

A second argument based on title may be directed toward passing only a one-half interest in the community property to the trustee in bankruptcy. If the bankrupt has title to only one-half of the community property, then under section $70 \mathrm{a}$ of the Act he lacks the requistie title necessary to pass the remaining community property to the estate. $^{102}$ However, this title theory seems inconsistent with the statutory concept of commumity property and with the creditors' remedies sections of the new community property law that allow creditors of either spouse to reach the entire community property. ${ }^{103}$ Passing ouly one-half of the community property to the bankrupt's estate would allow an unsecured creditor to reach fewer assets in bankruptcy then he could reach prior to the bankruptcy proceedings, contrary to a basic principle of the Act. ${ }^{164}$ In addition, the Bankruptcy Act would be an mefficient remedy indeed if no discharge could be granted to a bankrupt because all property accessible to the bankrupt's creditors had not been mcluded in the bankrupt's estate. Fortunately, however, even if a strict title theory does prevent the entire community property from passing autoinatically to the estate, it is clear that the power of the bankruptcy court to administer assets extends beyond property to which the bankrupt has title. The court may administer all property which is liable for the bankrupt's debts.

161. Even in a tenancy by the entirety system, if a creditor of only one spouse may reach the tenancy (an unusual situation), that spouse's interest in the tenancy will pass to the trustee in bankruptcy. King v. Green, 30 N.J. 395, 153 A.2d 49 (1959) (holding that in New Jersey the spouse's one-half interest was liable for claims of individual creditors); Dvorken v. Barrett, 100 N.J. Super. 306, 241 A.2d 841 (1968) (recognizing that such interest does pass to the trustee in bankruptcy). Thus, even if the community property is analogized to a tenancy by the entirety it will pass to the trustee, for the entire interest is liable for the claims of individual creditors.

162. See notes 57, 108 supra. Under the former law, a petition in bankruptcy would not sever the community property.

At the instance of the wife her interest [in the community property] could be segregated by a mutual contract between her and her husband; or in a divorce action; or a separate action based on a divorce action; or, on her death, by reason of the provisions of her will. Our statutes provide no other inethods. There are authorities to the effect that neither husband nor wife, except as we have recited, can force a division of the coinmunity property by partition, nor by a proceeding in equity.

Smedberg v. Bevilockway, 7 Cal. App. 2d 578, 581, 46 P.2d 820, 821 (1st Dist. 1935) (citation omitted). However, when Smedberg was decided, the wife had no title to the property. See text accompanying notes 33,34 supra. The title question (if indeed such inquiry is appropriate under a community property system) is open under the new community property law.

163. See text accompanying notes 79-86 supra.

164. Much of bankruptcy law is structured to allow unsecured creditors to reach more assets than they could have reached outside a bankruptcy context. See, e.g., Bankruptcy Act $\S 60 a, b, 11$ U.S.C. $\$ 96(a)$, (b) (1970); Bankruptcy Act $\$ 67 a, 11$ U.S.C. $\S 107$ (a) (1970). 
The United States Supreme Court recognized in Francis $v$. $M_{C N e a l^{185}}$ that the bankruptcy court has broad power to administer estates and nuarshal debts of non-bankrupts if such a procedure is necessary to achieve an equitable distribution of the bankrupt's estate. $^{106}$ Justice Holmes observed that:

[t]he business of [the Act] is so far as may be to preserve, not to upset, existing relations .... [W] see no reason for supposing that it was intended to erect a commercial device for expressing special relations into an absolute and universal formula-a guillotine for cutting off all the consequences admitted to attach . . . elsewhere than in the bankruptcy courts. ${ }^{167}$

He concluded by holding that "the rational thing to do, and one certainly not forbidden by the act is to administer [the non-bankrupt's estate] in bankruptcy." 168 In a bankruptcy involving community property, the bankruptcy court should similarly administer: the non-bankrupt's estate to prevent the bankruptcy proceeding fronl cutting off the rights of the bankrupt's creditors, who admittedly can reach the assets outside the bankruptcy context. Thus if a spouse is found to have title to only onehalf of the community property, the trustee may still take possession of and administer the community property of: the unadjudicated spouse insofar as this is necessary to settle the estate of the bankrupt spouse. ${ }^{100}$ Such a procedure will entail marshaling the claims of both spouses' creditors. ${ }^{170}$

The creditor's of the non-bankrupt spouse may certainly participate in the distribution of those community assets which do not automatically pass to the trustee. Regarding the community assets that do pass autoniatically to the trustee upon petition of the bankrupt (depending on the resolution of the title question), two alternative proposals are suggested for accomplishing an equitable distribution of assets to creditors of both spouses. Section 63 of the Act provides that "[d]ebts of the bankrupt may be proved ..., ,"171 and section 1 of the Act is specific in requiring the banksupt to be a person, which in-

165. 228 U.S. 695 (1913).

166. See text accompanying notes 271-72 infra. In Francis a partnership had been adjudged an involuntary bankrupt but an individual partner had not been successfully jomed in the petition. However, because the non-bankrupt partner's individual estate was fully liable for the claims against the bankrupt partnership, the referee ordered that this partner's separate estate be admimistered in the bankruptcy proceeding. The Supreme Court, per Justice Holmes, affirmed.

167. 228 U.S. at 700.

168. Id. at 701 .

169. Cf. 1A COLLIER ON BANKRUPTCY If 5.19 (14th ed. 1975). Title to this property would not vest until the trustee took possession. Id.

170. See text accompanying notes 87-105 supra.

171. 11 U.S.C. $\$ 103$ (1970). 
cludes partnerships, corporations and other legal entities. ${ }^{172}$ Seemingly then, California's individual debt doctrine, read in combination with section 63 of the Act, would permit only creditors of the bankrupt spouse to prove their claims, not creditors of the community. However, on equitable grounds, a court could hold that the language "debts of the bankrupt" is the equitable equivalent to "debts chargeable against the bankrupt's estate."173 If this solution is adopted, the bankruptcy court should then administer the community property apart from the separate estate and allow creditors of the non-bankrupt spouse to participate in the distribution of the cominunity assets. ${ }^{174}$ Such a solution, while contrary to the literal provisions of the statute, comports well with the policy of the Act.

An alternative solution, literally acceptable under the terms of the statute, but not supported by legislative history, ${ }^{175}$ would be to distribute

172. 11 U.S.C. $\$ 1$ (1970). Under subsection (4) only "persons" may be bankrupts. Subsection (23) defines person to include individuals, partnerships, corporations and other legal entities.

173. Under Proposed Act, supra note 6, $\$ 4-402$, claims of "creditors" are allowed to be charged against the estate. "Creditors" are defined to be persons who own claims against the estate of the debtor. Id. $\$ 1-102(15)$.

174. "It need hardly be said that, of course, the separate property of one spouse should not be subjected to the claims of the separate creditors of the other spouse . . .." DEFUNIAK \& VAUGHN, supra note 11, at 422 . However, this would be the case if the community property and separate property were administered together. Creditors of the non-bankrupt spouse-some of whose claims arose during activities not benefiting the community-would divide the community property and the separate property of the bankrupt pro rata. This would work-a particular hardship on the creditors of the bankrupt, who would be forced to share assets with creditors who could not reach those assets outside the bankruptcy proceedings and who would not suffer a discharge of their debts in the proceeding. See text accompanying notes 208-13 infra. In addition, unless the community property were administered separately, unsymmetrical distributions of the estate would result, depending upon the order in which the spouses filed petitions. See text accompanying notes $298-301$ infra. To prevent this, the community property, like partnership assets, should be administered separately. Nothing in the present Bankruptcy Act prohibits separate administration of the community estate, and this practice has long been utilized in community property states which classify obligations as "separate" and "community" debts. Moore, The Community Property System and Economic Reconstruction of the Family Unit: Insolvency and Bankruptcy, 11 WASH. L. REv. 61, 74 (1936) [hereinafter cited as Moore].

175. The legislative history of Bankruptcy Act $\$ 2(7), 11$ U.S.C. $\$ 11(7)$ (1970) provides:

The amendinent confers jurisdiction to determine and hquidate dower interests.

Prior to the decision of Isaacs $v$. Hobbs Tie \& Timber Co., (282 U.S. 734)

it was regarded as well settled that a bankrupt's estate could not be sold free of dower. See Kelly v. Minor (4 C.C.A., 252 F. 115). It is doubtful, certainly, whether the decision changed the rule. The jurisdiction granted by this clause seems essential to sell advantageously. The term "spouse" has been used to cover also any possible interest of the husband.

H.R. ReP. No. 1409, 75th Cong., 1st Sess. 20 (1937) (emphasis added). By use of the term "spouse," Congress did leave open the possibility of using section $2(7)$ for pur- 
a portion of community assets to the non-bankrupt's spouse in trust for his or her creditors through the conduit of section 2(7). ${ }^{176}$ This section provides in part:

The courts of the United States hereinbefore defined as courts of bankruptcy . . . are hereby invested . . . with such jurisdiction at law and in equity as will enable them to ... (7) Cause the estates of bankrupts to be collected, reduced to money, and distributed . . . and determine and liquidate all inchoate or vested interests of the bankrupt's spouse in the property of any estate whenever, under the applicable laws of the Ștate, creditors are enpowered to compel such spouse to accept a money satisfaction for such interest . . . .

While under the prior law the wife in California had a vested interest (for tax purposes) ${ }^{177}$ which was present, existing and equal, ${ }^{178}$ it is clear that her vested interest is nuch inore substantial under the new community property law; ${ }^{179}$ it includes the right to manage and control the community assets and arguably encompasses an inchoate right to have one's debts satisfied therefront. Although, a petition in bankruptcy by one spouse frustrates the other's right to manage and control the community property, it should not defeat the spouse's inchoate right to have his or her debts satisfied fronl community assets. This inchoate interest should be hquidated under section $2(7)$ by allowing the creditors of the non-bankrupt to share in the distribution of the community estate. ${ }^{180}$ Under whichever theory the court wishes to proceed-full title to the community property in the bankrupt, passing to the trustee under section $70 \mathrm{a}(5)$ or title to one-half the community assets (passing under $70 \mathrm{a}(5)$ to the trustee) and acquisition of the remaining half of the community assets under the equitable doctrine of Francis v. McNeal, the result is the same: all the community property is administered in the bankruptcy proceeding and creditors of both spouses share in its distribution. ${ }^{181}$ There is no rationale for cutting off the rights

poses other than a dower interest. The present community property dilemma is arguably just such a situation. Furthermore, using section 2(7) for purposes other than a dower interest would be in accord with the broad policy behind other provisions of section 2(7) which were enacted so as to implement more efficiently the purposes of the Bankruptcy Act. See 1 Collier on BANKRUPTCY $\pi 2.42$ at 268.3-276 (14th ed. 1974).

176. 11 U.S.C. $\$ 11(\mathrm{a})(7)(1970)$.

177. See text accompanying notes 33,34 supra.

178. See text accompanying note 31 supra.

179. See text accompanying notes 69-86 supra.

180. Such a procedure divides the community property before it is combined with separate property to constitute the estate of the bankrupt and thus circumvents the problem discussed in note 174 supra.

181. In the partnership situation, only the excess of the individual assets over the individual liabilities is available to the trustee, presumably because of the jingle rule in bankruptcy administration of partnership estates. 1A COLLIER ON BANKRUPTCY $\ 5.19$ (14th ed. 1975). See notes 182, 183 infra. No justification can be advanced that would so limit the community property available to the trustce, because creditors of the other 
of creditors against all the community assets available to them outside bankruptcy. On equitable grounds, those creditors of either spouse who have contributed to the growth of the entire community property should have a right to reach all community assets. If the claims of creditors of one spouse account for 90 percent of the claims against the estate, it would be inequitable to limit these creditors to half the assets while the other spouse's creditors, representing 10 percent of the claims, reap 50 percent of the assets. Thus all creditors should participate in the distribution of the estate.

\section{Distribution of the Estate}

One way to accomplish distribution of the liquidation proceeds would be to adopt a "jingle rule" for administration of the estate. ${ }^{182}$ Such a rule would marshal the debts incurred for the benefit of the community against the community property and debts incurred during separate activities against the separate property. Any excess assets would be contributed to satisfy the other form of claim. Creditors of both spouses holding "community claims" would thus divide the community property pro rata. However, the jingle rule in partnership estate administration has come under increasing attack ${ }^{183}$ and will be partially abolished if the Proposed Act is adopted. ${ }^{184}$ Furthermore, the jingle rule is wholly inappropriate under the California community property system, for it violates the rule that community property and separate property of a spouse are equally liable for the postnuptial debts of that spouse. ${ }^{185}$ Thus while assets nay be marshaled if the debtor is solvent, sucli a procedure should not be solidified into a jingle rule to the detriment of creditors.

The only equitable means of determining a spouse's interest in

spouse may reach all the community assets without marshaling the other spouse's debts and assets. The one exception to this would be the business assets of the non-bankrupt spouse which should be treated like partnership property because business debts of the non-bankrupt would be marshaled under state law. See text accompanying notes 10633 supra.

182. See Bankruptcy Act $\$ 5 g, 11$ U.S.C. $\$ 22(\mathrm{~g})(1970)$.

183. Kennedy, A New Deal for Partnership Bankruptcy, 60 Colum. L. Rev. 610, 630-32 (1960). MacLachlan, Partnership Bankruptcy, 65 CoM. L.J. 253, 256-57 (1960). See Report of the Commission of the Bankruptcy Laws of the United States, H.R. Doc. No. 137, Part II, 93d Cong., 1st Sess. 115 [hereinafter cited as RePort: PART II; Part I will be cited as RePort: PART I].

184. Under the Proposed Act, creditors of the partnership will divide the partnership assets pro rata, with any excess going to the individual estates; however, both partnership and separate creditors will divide the individual estate pro rata. Proposed Act, supra note $6, \S 4-405(\mathrm{f})$. This is more in keeping with the state law rights of creditors.

185. Under California law it would be untenable to allow creditors holding claims incurred for the benefit of the community to be paid in full while other creditors of a spouse suffer. See text accompanying notes $37-41$ supra. 
community property is to allow each creditor having a claim against the community property to charge the claim against those assets. This accomplishes a pro rata distribution of the community property among all creditors having claims capable of being satisfied from the community property. All creditors of the husband and wife (whether or not their claims were incurred during activities benefiting the commumity) would divide the community property on a pro rata basis determined by the aggregate size of their claims and appropriate inarshaling of the nonbankrupt's assets. ${ }^{186}$ Such a result satisfies the California requirement that creditors holding claims incurred in a spouse's separate capacity and creditors holding debts incurred for the benefit of the community be treated equally. The result is as if the spouses had assigned their community property for the benefit of creditors. Such a pro rata distribution of community assets to unsecured creditors of the bankrupt and non-bankrupt has recently been adopted in Texas. ${ }^{187}$

\section{Non-recognition of California's Limitation on Creditors' Remedies}

Apportionment of the community property among the spouses' creditors under the new California community property law raises an interesting question which did not arise under the former law. Under the law prior to 1975 , a petition by the husband passed all community property under his management and control to the trustee; this did not include personal injury damage awards or uncommingled wages of the wife. ${ }^{188}$ All the property passing to the husband's trustee was fully liable for all claims of his creditors under state law. No distinction could be drawn between any of the husband's creditors; prenuptial and postnuptial creditors' rights were coextensive, each entitled to reach all separate property and community property in the bankrupt's estate. However, under the new community property law, although a spouse has nianageinent and control of the other spouse's wages, ${ }^{180}$ that spouse's prenuptial creditors may not reach those assets. ${ }^{100}$ The question is, therefore: Should these state priorities be recognized in bankruptcy?

186. Debts incurred by the non-bankrupt during activities not benefiting the community should be marshaled against the non-bankrupt's separate estate to the extent possible. Debts incurred by the non-bankrupt during activities benefiting the community should not be marshaled against the separate estate of the non-bankrupt, for to do so would harm the non-bankrupt who has a right to have his or her debts incurred during community activities satisfied from the community property. See text accompanying notes 87-105 supra.

187. Cockerham v. Cockerham, 527 S.W.2d 162, 172 (Tex. 1975).

188. See text accompanying notes 52-62 supra.

189. CaL. CIv. Code $\$ 5125$ (a) (West Supp. 1975); see text accompanying notes 69-73 supra.

190. CaL. CTv. Code $\$ 5120$ (West Supp. 1975). Such creditors may also be barred from the community property interest in the other spouse's business. See note 81 supra. 
Maintaining the state law priorities of each of the creditors of the bankrupt could be accomplished mathematically. One need only establish eaclı type of asset as a separate mini-estate and then allow each claim chargeable against that type of asset to share pro rata. ${ }^{191}$ However, the administrative problems inherent in such a systein undoubtedly outweigh any fairness that might be involved in maintaining these priorities; furthermore, such a scheme is not defensible under the Bankruptcy Act.

Section 64 of the Bankruptcy Act ${ }^{192}$ sets forth the priorities that are allowed in the administration of a bankrupt's estate. Reading in of other priorities based on state law is not favored. ${ }^{193}$ Under section 63 , debts of the bankrupt may be proved against his estate; no qualification is made as to those debts allowable only against a portion of that estate. Furthermore, allowing creditors to reach more assets inside the bankruptcy court than they had access to under state law is not uncominon, ${ }^{104}$ and the effect here is likely to be insignificant. ${ }^{195}$ Thus, the bankruptcy court need not and should not recognize the distinction California makes between prenuptial and postnuptial creditors of a spouse, because each creditor may at least reach a portion of the community assets. For purposes of bankruptcy administration, only creditors of the husband and creditors of the wife should be recognized. ${ }^{100}$

191. Such a procedure would require one to establish categories such as "wife's separate property," "wife's wages," "community property," "husband's wages," "business interest" and "husband's separate property" and then charge each of these estates with the claims of those creditors of each spouse who could reach these assets outside the bankruptcy context. For example, a prenuptial contract creditor of the wife would charge his claim against the wife's separate property, her wages, and the community property, while a postnuptial contract creditor would be able to reach, in addition to the estates mentioned, the husband's wages and the "community interest" in the business. See Part II supra.

192. 11 U.S.C. $\$ 104$ (1970).

193. 3A Collier on BANKRUPtcy If 64.02 at 2074.1-2075 (14th ed. 1975).

194. See, e.g., Bankruptcy Act $\$ 60 a, b, 11$ U.S.C. $\$ 96(a)$, (b) (1970); Bankruptcy Act $\$ 67 a, 11$ U.S.C. $\$ 107$ (a) (1970); Bankruptcy Act \& 67d, 11 U.S.C. \$ 107 (d) (1970); Bankruptcy Act $\$ 70$, 11 U.S.C. $\$ 110($ e) (1970); Moore v. Bay, 284 U.S. 4 (1931).

195. The only effect would be that prenuptial creditors would share pro rata in the distribution of the other spouse's wages and the "community interest" in the other spouse's business. See text accompanying notes $81,106-29$ supra.

196. This situation should be distinguished from the situation involving creditors of the other spouse. See note 174 supra. In that case, property of a third party (the bankrupt's separate assets) was not distributed to creditors of the other spouse who could not reach such property under state law. Here, the community property being distributed is property belonging to both spouses. Furthermore, the non-bankrupt spouse's creditor's claims were only provable on equitable grounds, and equitable considerations limited those claims to the community assets under the section 67 procedure. See text accomnanving notes $171-74$ suora. Under the section $2(7)$ solution this problem does 
Finally, the liquidation in bankruptcy of an estate containing a sole proprietorship should not result in the priorities accorded business creditors under state law. ${ }^{197}$ While the business was a going concern, legislative policy dictated on equitable grounds that the court should protect the business spouse. However, when the sole proprietorship is in liquidation, no such equitable considerations exist, and the rights of creditors of the non-business spouse should not be subrogated to the claims of the business creditors. Under Civil Code section 5116, the assets are liable for the claims of both spouses. Accordingly, the assets of the sole proprietorship should be coinbined with the other community property in the estate and distributed to creditors of both spouses. ${ }^{108}$

\section{The Insolvency Test}

The test for insolvency under the Act is thought to be a simple balance sheet comparison of assets and liabilities; however, when this test is coinbined with the complexities of the community property system, the result is less than straightforward. The problem stems from the statutory definition of insolvency. For these purposes section 1(19) of the Act provides that "[a] person shall be deemed insolvent . . . whenever the aggregate of his property . . . shall not at fair valuation be sufficient in amount to pay his debts." ${ }^{100}$ It is immediately apparent that the definition is not well suited to a cominumity property system because claims of both spouses' creditors agamst the community property should be included. In addition, while the interpretation of the insolvency test is independent of the questions involved with the property of the bankrupt's estate and his discharge, the provisions must be consistent. Because of the nature of the bankrupt's estate, ${ }^{200}$ the assets to be included in the balance sheet test are a spouse's separate estate, all non-business community property (including rights of repayment from the other spouse's separate property), ${ }^{201}$ the spouse's busimess, and the

not arise because the community property is divided before it becomes part of the bankrupt's estate. See text accompanying notes 175-80 supra.

197. See text accompanying notes 117-29 supra.

198. A different result would be reached under a Chapter XI arrangement involving a sole proprietorship. Bankruptcy Act $\$ \S 301-99,11$ U.S.C. $\$ \S 701-99$ (1970). In that case the business, though insolvent, is a going concern. Under state law there would be no "community interest" in the business because the debtor is insolvent. See note 125 supra. Therefore, a plan of arrangement need not involve creditors of the non-petitioning spouse, for they have no rights against the business so long as it is insolvent and the plan of arrangement is in effect.

199. Bankruptcy Act $\S 1(19), 11$ U.S.C. $\S 1(19)$ (1970) (emphasis added). For a discussion of this section see 1 CollIER ON BANKRUPTCY $\mathbb{1} 1.19$ at 114-21 (14th ed. 1974).

200. See text accompanying notes 145-52 supra.

201. For a discussion of the right of reimbursement see note 91 supra. 
"community interest" in the other spouse's business. The debts chargeable against this estate consist of all debts of the bankrupt, the debts incurred during activities benefiting the community by the other spouse, and the excess of the other spouse's other debts to the extent that they exceed his or her separate property. ${ }^{202}$ If these liabilities exceed the assets, the spouse is insolvent for purposes of an involuntary petition under section 4 of the Act.

\section{The Avoiding Powers}

The avoiding powers of the Bankruptcy Act should be available to the trustee of one spouse against voluntary or involuntary transfers of community property by the other spouse, for such powers are necessary to enable the trustee to equitably distribute the assets of the community among all creditors. Under section $60 \mathrm{a}, \mathrm{b}$ of the Act, ${ }^{203}$ the only issue would be whether a conveyance by the non-bankrupt spouse would constitute a "transfer ${ }^{204} \ldots$ of any of the property of the debtor . . . suffered by such debtor while insolvent." Seemingly, actions by the nonbankrupt spouse do fit this description, because section 60 is concerned with transfers of the debtor's property, not transfers by the debtor.

Section 67a of the Bankruptcy Act ${ }^{205}$ allows the trustee to void any lien against property of the debtor obtained by attachment, judgment, levy, or other legal or equitable process or procedure within 4 months of bankruptcy. Because the community property is property of the debtor, it falls within section $67 \mathrm{a}$ and therefore allows the trustee to avoid liens on community property resulting from claims of the other spouse's creditors. Similar results follow from an analysis of sections $67 \mathrm{~d}^{206}$ and $70 \mathrm{e}^{207}$ of the Bankruptcy Act, whicl are both concerned with "transfers suffered by the debtor" against "property of the debtor." In short, the rights of trustees are unimpaired by a preferential transfer, fraudulent conveyance, or lien made or suffered by the non-bankrupt spouse.

202. This test is an updated version of the one given in 1 CoLIIER ON BANERUPTCY II 1.19 at 117 (14th ed. 1974). The limitation on the separate debts is due to the marshaling of these debts against the non-bankrupt spouse's separate property. See text accompanying notes 87-105 and note 186 supra.

203. 11 U.S.C. $\$ 96(a)$, (b) (1970).

204. A transfer is broadly defined to include:

the sale and every other and different mode, direct or indirect, of disposing of or of parting with property or with an interest therem or with the possession thereof or of fixing a lien upon property or upon an interest therein, absolutely or conditionally, voluntarily or involuntarily, by or without judicial proceedings, as a conveyance, sale, assignment, payment, pledge, mortgage, lien, encumberance, gift, security, or otherwise . . . .

Bankruptcy Act § 1(30), 11 U.S.C. \$ 1(30) (1970).

205. 11 U.S.C. \& 107 (a) (1970).

206. 11 U.S.C. $\$ 107(\mathrm{~d})(1970)$.

207. 11 U.S.C. $\$ 110(\mathrm{e})(1970)$. 


\section{E. Discharge of the Bankrupt}

Under the former law, because a bankruptcy petition by or against the husband passed title to both his separate property and all the community property subject to the claims of his creditors, a discharge of the husband discharged all debts collectible out of the assets passing to the trustee. ${ }^{208}$ In General Insurance Co. v. Schian, ${ }^{200}$ a husband and wife had guaranteed an obligation and the debts of the husband had been discharged in a subsequent bankruptcy proceeding. The court held that the discharge released all community property under the management and control of the husband frone liability on the debt and that the non-discharged guarantee of the wife entitled the creditor to satisfy lis claim only from the wife's separate property and comnuunity property under her management and control.

Under the commumity property laws as they existed at that time, the Schian liolding was correct. The guarantee was a joint and several obligation of the husband and the wife. After discliarge of the husband, only the wife's obligation remained enforceable, and, under the law at that time, her creditors had no right to reach the community property under the nuanagement and control of the husband. The new community property law should overrule the result in Schian because after January 1,1975 , the community property is liable for the wife's debts. ${ }^{210}$ The general rule is that where one spouse is personally liable, the discharge of the other spouse has no effect. ${ }^{211}$ This being so, a spouse's creditors should be allowed to reacls the community property acquired after a discharge of the other spouse.

Allowing creditors of the non-bankrupt spouse to reach subsequently acquired community property may frustrate the "fresh start" doctrine of the Bankruptcy $\mathrm{Act}^{212}$ by permitting newly acquired proper-

208. A discharge should not be granted vis-à-vis non-exempt property not passing to the estate. This would exempt separate property of the non-bankrupt which is liable for necessity debts incurred by the spouse. Such separate property could be collected for the estate, allowing a full discharge of the debtor, or it could be exempted from discharge. See note 62 supra. To administer the separate property in the estate would involve marshaling all assets and liabilities of the non-bankrupt. The non-bankrupt's claim to reimbursement from community property expended to pay separate debts of the bankrupt should also be discharged.

209. 248 Cal. App. 2d 555, 56 Cal. Rptr. 767 (1st Dist. 1967).

210. The Court in Schian distinguished Flores v. Bailey, 341 S.W.2d 473 (Tex. Civ. App. 1960), which had allowed a wife's creditors to reach community property acquired subsequent to a discharge of the husband on the ground that in Texas, at that time, such property was liable for the wife's debts if the husband had joined in the execution of the contract. Flores should now be persuasive in California. Also see Durian v. Curl, 155 Tex. 377, 286 S.W.2d 929 (1956); Cullum v. Lowe, 9 S.W.2d 70 (Tex. Ciy. App. 1928).

211. D. Cowans, BanKRuptcy LaW and Practice $\$ 725$ at 371 (1963).

212. See Local Loan Co. v. Hunt, 292 U.S. 234 (1934); Lines v. Frederick, 400 
ty to be immediately seized by the non-bankrupt's creditors who have already been partially satisfied from the bankrupt's estate. However, the fact that the non-bankrupt's creditors are allowed a second bite at the apple should not be offensive-after all, they are owed the money. It should be remembered that a discharge is not a punishment for creditors; it is $a_{1}$ right earned by the bankrupt. A spouse who has not submitted to the burdens imposed by the Bankruptcy Act should not enjoy the benefits of the Act simply because his or her creditors have been partially satisfied in a related proceeding. Furthermore, the only relief that could be afforded such a spouse would be a split discharge, for the spouse's separate property has not been distributed to creditors. Finally, if the spouses wish to have a fresh start, they may both declare bankruptcy and settle all their debts. It is for these reasons that the Bankruptcy Act provides no means to discharge any person other than the bankrupt. ${ }^{213}$

IV

\section{Other Community Property States}

This section will briefly discuss the community property systems of the six other states that have recently adopted equal management community property laws. ${ }^{214}$ No attempt will be made to discuss the law of any state in depth; rather, the discussion will focus on managerial

U.S. 18 (1970); Segal v. Rochelle, 382 U.S. 375 (1966); Comment, Bankruptcy: The Disposition of the Debtor's Unliquidated Cause of Action for Personal Injuries, 63 CaLIF. L. Rev. 579 (1975).

213. Bankruptcy Act $\$ 14,11$ U.S.C. $\$ 32$ (1970); Young, Joint Management and Control of Community Property in Idaho: A Prognosis, 11 IDAHo L. Rev. 2, 8 (1974) [hereinafter cited as Young]. The statement in 1 CoLLIER ON BANKRUPTCY $\pi 1.19$ at 116 (14th ed. 1974) that "the wife should be relieved from any continued liability [following a discharge of the husband] with respect to newly acquired community property, at least where her liability exists only with respect to, and not independent of, her community property rights" must be read in context. It is addressing the situation where, under the prior law, the wife's necessity creditors could reach both property of the community and the lusband's separate property. Having once done this they should be discharged vis-à-vis the property under the husband's sole management and control. However, under the new community property law, where the wife is independently liable for such claims and may control the community property in her own right, a discharge of the husband should not discharge the wife's creditors except in regard to the husband's separate property, which is not under the wife's control.

214. For a discussion of the community property laws of each of these states under their prior laws, see DEFuniak \& VAUGHN, supra note 11; Lyons, Development of Community Property Law in Arizona, 15 LA. L. Rev. 512 (1955); Brockelbank, The Creditor and the Community In Idaho, id. at 535; Jacob, The Law of Community Property in Idaho, (pts. 1-2) 1 IDAнHo L.J. 1, 118 (1931); Shermack, Nevada Community Property Law, 15 LA. L. Rev. 559 (1955); Clark, New Mexico Conmunity Property Law: The Senate Interim Committee Report, id. at 571; Huie, Some Principles of Texas Community Property Law, id. at 605; Cross, The Community Property Law in Washington, id. at 640 . 
control of the community property and on those creditors' remedies provisions fundamental to the determination of the estate in bankruptcy under section 70(a)(5) of the Bankruptcy Act. ${ }^{215}$ The information presented here will also serve as a basis for the subsequent discussion of the sections of the Proposed Act relating to community property.

\section{A. Arizona}

Under Arizona law, separate property is under the sole managenient and control of each spouse. ${ }^{216}$ The spouses have equal management and control of the community property and either spouse may bind or encumber personal property; transactions involving real property generally require joimder of both spouses. ${ }^{217}$ No provision is made for sole managenient of a community property business. In addition, Arizona's new community property law partially rejects the "conımunity" and "separate" debt distinction that once prevailed in the state; ${ }^{218}$ however, the new provision dealing with separate debts was not nrade retroactive. ${ }^{219}$ Thus, separate debts incurred after September 1, 1973, may be satisfied from a spouse's separate property and front the community property to the extent of that spouse's contribution to the community, ${ }^{220}$ while separate debts incurred prior to September 1, 1973, are satisfied only froin a spouse's separate property. ${ }^{221}$ On the other hand, community debts are satisifed first from community property, then from the separate property of the contracting spouse. ${ }^{22}$ The separate property of one spouse is not liable for the separate debts of the other spouse. ${ }^{22 B}$

215. See text accompanying note 52 supra.

216. ARIZ. REv. StAT. ANN. \$ 25-214A (Supp. 1973).

217. ARIZ. Rev. Stat. ANN. \$\$ 25-214B, C (Supp. 1973).

218. Under the former law, Arizona strictly adhered to the distinction between separate and community obligations. Former ARIz. REv. STAT. ANN. $\$ 25-216$ (repealed 1973). Separate obligations of a spouse could not be satisfied from community property. Prater v. United States, 268 F. Supp. 754 (D. Ariz. 1967); Barr v. Petzhold, 77 Ariz. 399, 409, 273 P.2d 161, 167 (1954).

219. ARtz. Rev. Stat. ANn. \$ 25-215B (Supp. 1973); McKee v. Conkle, 23 Ariz. App. 249, 532 P.2d 191 (1975).

220. Id.

221. Id.

222. ARIz. Rev. Stat. ANN. $\& 25-215 D$ (Supp. 1973). No special provision is made for necessity creditors under the new statute. See former ARIz. REv. STAT. ANN. \$ 25-215 (repealed 1973).

223. Ariz. Rev. Stat. AnN. \& 25-215A (Supp. 1973). It is arguable from a rcading of subsections $A$ and $D$ together that the separate property of a spouse is liable for the community debts of the other spouse. Subsection A exempts only separate property from liability for separate debts of the other spouse. Subsection D declares that the spouse shall be sued jointly and that community debts shall be satisfied first from community property, then from the separate property of the contracting spouse. It does not exempt the other spouse's separate property. However, under the prior law, the wife's separate property was not liable for the community debts of the husband. 
In bankruptcy, a petition by or against one spouse should pass all that spouse's separate property and all community property to the trustee. ${ }^{224}$ As in California, the community property should be divided pro rata among the creditors able to reach any part of such property outside the bankruptcy court. This implies that all community creditors of either spouse and separate creditors of either spouse whose claims arose after September 1, 1973, should divide the community assets pro rata. $^{225}$ All (and only) creditors of the bankrupt should divide the bankrupt's separate property.

\section{B. Idaho}

In Idaho, separate property is controlled individually by each spouse. ${ }^{226}$ Either spouse may inanage and control community property except that the spouses nust join in real property transactions. ${ }^{227}$ No provisions for sole nanagement of a community business are made.

Idaho is similar to California in that neither spouse is liable for the obligations of the other unless that spouse consents to such liability in writing;:228 however, no statutory provisions define the rights of creditors against the community assets. ${ }^{29}$ Under the former community property law, the community property was liable for all debts of the husband,

This may indicate that the liability for community debts does not extend to the other spouse's separate property. See former ARIz. Rev. Stat. ANN. \$ 25-215 (repealed 1973). In addition, no other community property state recognizes such liability either by statute or by case law; however, the question is open in Washington. See note 263 infra.

224. Because a spouse has management and control over the entire community and because a spouse's creditors may reach the entire community property, it is assumed that the spouse will be found to lave "title" to all the community assets. If so, under Bankruptcy Act $\$ 70 a(5), 11$ U.S.C. $\$ 110(a)(5)(1970)$, the separate property of a spouse and all the community property may be levied upou by the spouse's creditors; therefore, it passes to the trustee in bankriptcy. See text accompanying note 52 supra. Even if title to only one-half of the community property is established, the trustee may acquire all the community assets under the doctrine of Francis v. McNeal. See text accompanying notes 162-81 supra. Under the former law, a petition by the husband passed all his separate property and the community property to the trustee, but did not affect the wife's separate property. Valley Nat. Bank v. Fulton, 77 Ariz. 11, 15, 266 P.2d 397, 399 (1954).

225. Once the community property is acquired by a spouse's trustee, the question arises whether the pre-September 1, 1973 separate creditors should share in the distribution of the community assets. Seemingly they should not. The admistration of the spouse's bankruptcy should involve two estates: the community property estate available to only community creditors and those separate creditors whose claims arose after September 1, 1973, and a separate estate available to all creditors of the bankrupt. See Moore, supra note 174, at 74 and note 174 supra.

226. IDAHO CODE $\$ 32-904$ (1963).

227. IDAHO CODE $\$ 32-912$ (Supp. 1975).

228. Id.

229. For a discussion of creditors' remedies and community property prior to the statutory changes in Idaho, see Brockelbank, The Creditor and the Community in Idaho, 15 LA. L. Rev. 535 (1955). 
whether or not incurred during community activities. ${ }^{280}$ It nuust be assumed that because the wife now possesses that control, her creditors will also be able to reach both the community property and her separate assets. ${ }^{231}$ If this is so, the laws of California and Idaho are very similar, and bankruptcy administration in Idaho should closely parallel that of California. ${ }^{232}$

\section{Nevada}

Nevada was the seventh and most recent state to adopt an equal inanagement community property law. ${ }^{233}$ Uncler Nevada law, separate property is under the sole management and control of its owner. ${ }^{284}$ Either spouse may manage the community property, although real property transactions require the consent of both spouses. ${ }^{235}$ Business transactions, if the busmess is operated jointly by both spouses, must be made jointly; otherwise, the business spouse may act unilaterally. ${ }^{280}$ As far as creditors' rights are concerned, prenuptial creditors may reach a spouse's separate property and that spouse's interest in the community property. ${ }^{237}$ Necessity creditors of the wife are satisfied first from the community, then from the husband's separate property. ${ }^{238}$ It is unsettled whether or not Nevada follows the community and separate debt doctrine, ${ }^{239}$ however, the modern trend seenus to be that the community is at

230. Holt v. Empey, 32 Idaho 106, 110, 178 P. 703, 704 (1919).

231. For a discussion of creditors' remedies nnder Idaho's new law, see Young, supra note 213 , at $4-8$.

232. See text accompanying notes 145-96 supra. Apparently Idaho, like California, does not follow the community debt doctrine. It only recognizes debts of the husband and debts of the wife. See Brockelbank, supra note 2.29.

233. NEV. REv. STAT. $\S \S 123.010-.250$, ch. 393, $\S 1-18$, [May 10, 1975] Nev. Stat. 557-62 (Advance Sheets).

234. NEv. REv. Stat. \& 123.170 , ch. 393 , \& 13, [May 10, 1975] Nev. Stat. 560 (Advance Sheets 1975).

235. Nev. Rev. Stat. $\S \$ 123.230$ (c)-(e), ch. 393, $\$ 16$, [May 10, 1975] Nev. Stat. 561 (Advance Sheets 1975). This statute closely resembles the Washington statute providing equal management and control over the community property by the spouses. See WASH. REV. CODE $\$ 26.16 .030$ (Supp. 1974).

236. Nev. Rev. Stat. $\$ 123.230$ (f), ch. 393, § 16, [May 10, 1975] Nev. Stat. 561 (Advance Sheets 1975).

237. Nev. Rev. Stat. $\S 123.050$, ch. 393, $\$$, [May 10, 1975] Nev. Stat. 558 (Advance Sheets 1975).

238. Nev. Rev. Stat. $\$ 123.090$, ch. 393, \& 7 [May 10, 1975] Nev. Stat. 558 (Advance Sheets 1975).

239. In Randono v. Turk, 86 Nev. 123, 466 P.2d 218 (1970), it was held that community property was liable for the separate debts of the husband because he could unilaterally give the property away and because the property was liable for such debts upon his death under former Nev. REv. STat. $\$ 123.260$ (1973). 86 Nev. at 132, 466 P.2d at 224. Neither of these bases for finding such liability now exists. Section 123.260 was repealed by the amendments to the community property laws, ch. $393, \S 18$, [May 10, 1975] Nev. Stat. 562 (Advance Sheets), and neither spouse may make a gift 
least partially liable for separate debts of the spouses. ${ }^{\mathbf{2 4 0}}$

Bankruptcy administration in Nevada will, of course, be influenced by the resolution of the community debt question. Nevertheless, it is clear that a petition by either spouse should pass all that spouse's separate property and the community property to the trustee. ${ }^{241}$ Those creditors who may reach the community property outside bankruptcy should then share pro rata in its distribution. No restriction should be placed on prenuptial creditors; they should be allowed to share pro rata in distribution of the community property because they may reach a portion of the community property outside of bankruptcy. ${ }^{242}$

\section{New Mexico}

In New Mexico, spouses individually manage and control their separate personal property and separate real property not held as tenant in common or in joint tenancy with the other spouse. ${ }^{243}$ Either spouse alone may manage and control community personal property, ${ }^{244}$ while community realty as well as tenancies held in common or jointly with the other spouse require joint management by the spouses. ${ }^{245}$ No special provision is made for community property business. ${ }^{246}$ In the area of creditors' rights, New Mexico distinguishes between commumity and separate debts by providing an elaborate marshaling scheme which, in the extreme, limits separate creditors to all of a spouse's separate property and one-half of the community property. ${ }^{247}$ Community creditors may reach the debtor's separate property and all of the community property, but may not reach the other spouse's separate property unless the other spouse is jointly and severally liable for the claim. ${ }^{248}$

of the community property without the consent of the other. NEv. Rev. STAT. $\$$ 123.230(b), ch. 393, \& 16, [May 10, 1975] Nev. Stat. 561 (Advance Sheets 1975).

240. In Nevada, a prenuptial creditor-one type of separate creditor-may reach a portion of the community property. Nev. REv. STAT. $\$ 123.050$, ch. 393 , $\$ 6$, [May 10, 1975] Nev. Stat. 558 (Advance Sheets 1975). Similarly, separate creditors in Arizona, New Mexico and Washington are now allowed at least partial access to the community property. In all other community property states separate creditors are allowed full access to community assets, with the non-debtor spouse having only a right of reimbursement from the other spouse for his or her share of the community property so used.

241. Bankruptcy Act $\$ \S 70 a(5), 70 c, 11$ U.S.C. $\$ \S 110(a)(5), 110(c)(1970)$. See text accompanying note 52 and note 224 supra.

242. See text accompanying notes 187-96 supra.

243. N.M. Stat. \$ 57-4A-7(A) (Interim Supp. 1975). For a discussion of New Mexico's 1973 Community Property Act, see Bingamen, The Community Property Act of 1973: A Commentary and Quasi-Legislative History, 5 N. M. L. REv. 1 (1974).

244. N.M. STAT. \$ 57-4A-8(A) (Interim Supp. 1975).

245. N.M. STAT. \$ 57-4A-7(A) (Interim Supp. 1975).

246. The community property business was to have been presumptively managed by the husband. Former N.M. STAT. \$ 57-4A-7.1(A) (Supp. 1973) (repealed 1975).

247. N.M. Stat. \& 57-4A-4(A) (Interim Supp. 1975).

248. N.M. STat. \& 57-4A-5(A) (Interim Supp. 1975). 
The bankrupt's estate in New Mexico should include all the community property and the separate property of the bankrupt. ${ }^{240}$ The distribution of the community assets which do pass to the trustee should be divided pro rata among all creditors of both spouses subject to marshaling considerations, because even the separate creditors of the bankrupt may reach a portion of the community property. ${ }^{250}$

\section{E. Texas}

In Texas, separate property is under the sole management and control of each spouse. ${ }^{251}$ The community property is divided into three types: (1) community property under the joint manageinent and control of the spouses; (2) community property under the sole management and control of the husband; and (3) community property under the sole management and control of the wife. ${ }^{252}$ The community property under the sole control of a spouse is primarily wages, revenue from separate property and personal injury recoveries. ${ }^{253}$ All other community property is jointly controlled. ${ }^{254}$ Texas, like California, does not adhere to the commumity debt doctrine. Creditors of a spouse, whether or not the debt was incurred in community or separate activities, or before or after marriage, may reach that spouse's separate property, the community property under that spouse's sole management and control, and the community property under joint management and control. ${ }^{255}$ Postnuptial tort creditors nuay in addition reach the community property under the sole management and control of the non-debtor spouse. ${ }^{256}$

Administration of the bankrupt's estate in Texas should closely resemble estate administration in California. The property of the estate

249. Assuming each spouse has title, this is property upon which the spouse's creditors may levy. See text accompanying note 52 and note 224 supra.

250. All creditors, whether separate or community, should share equally in the estate. The marshaling provisions involving separate creditors should not apply so long as these creditors are not being paid in full.

251. TEX. FAM. CODE $\$ 5.21$ (1975). For a definition of separate and community property see TEX. FAM. CODE $\$ 5.01$ (1975). McKnight, The Texas Family Code Symposium (Title 1. Husband and Wife), 5 TEx. T. L. Rev. 281 (1974) provides a legislative and judicial history of the Texas Family Code provisions relating to husband and wife [hereinafter cited as McKnight].

252. TeX. FAM. CODE $\$ 5.22$ (1975); Evans v, Muller, 510 S.W.2d 651 (Tex. Civ. App. 1974), rev'd on other grounds, 516 S.W.2d 923 (Tex. 1975); Cookerham v. Cockerham, 527 S.W.2d 162 (Tex. 1975).

253. Tex. FAM. CODE $\S 5.22(\mathrm{a})$ (1975). Cooper v. Texas Gulf Ind. Inc., 513 S.W.2d 200, 202 (Tex. 1974); Williams v. Saxon, 521 S.W.2d 88, 90 (Tex. Civ. App. 1975); Williams v. Portland State Bank, 514 S.W.2d 124 (Tex. Civ. App. 1974).

254. TEX. FAM. CODE $\$ 5.22$ (c) (1975).

255. TEX. FAM. CODE $\$ \S 5.61$ (a), (c) (1975). Separate property of the other spouse is not liable. Texas Comm. Bank Nat. Ass'n v. Tripp, 516 S.W.2d 256, 259 (Tex. Civ. App. 1974).

256. TEX. FAM. CODE $\S \S 5.61(b)$, (d) (1975). 
should be the bankrupt's separate property and the community property under the sole or joint control of the bankrupt. ${ }^{257}$ It is an open question whether the community property under the sole control of the other spouse should be administered. ${ }^{258}$ Subject to marshaling considerations,

257. This is property over which the bankrupt has title and which may be transferred by the bankrupt or levied upon by his or her creditors. This result was recently recognized in Cockerham v. Cockerham, 514 S.W.2d 150, 158-59 (Tex. Civ. App. 1974), aff'd in part, 527 S.W.2d 162 (Tex. 1975). See note 224 supra.

258. If, under Texas law, the bankrupt spouse has sufficient title to the community property under the sole management and control of the other spouse, a court must decide whether such property may be transferred by the bankrupt or levied upon by any means. See note 224 supra. Under TEX. FAM. CODE $\$ 5.22$ (1975), such property may not be transferred by the bankrupt. The availability of such property to levy and sale by creditors of the bankrupt is unsettled. Because such property may not be transferred by the bankrupt, it should be exempt from levy and sale by the bankrupt's creditors: "The true rule as to property which can be levied on by a writ of execution and sold ... [is where the debtor] possesse[s] such an interest in the property as might be transferred by assignment . . . ." Jenson v. Wilkinson, 133 S.W.2d 982, 986 (Tex. Civ. App. 1939) and cases cited therein. However, community property cases have allowed creditors of the wife to levy on community property under the sole management and control of the husband when such property was hable under state law. Durian v. Curl, 155 Tex. 377, 286 S.W.2d 929 (1956); Flores v. Bailey, 341 S.W.2d 473 (Tex. Civ. App. 1960). Professor McKnight states that it was the intent of the legislature to allow levy by one spouse's tort creditors on the community property under the sole management and control of the other spouse. McKnight, supra note 251, at 382. If this is so, then the community property under the sole management and control of the non-bankrupt would pass to the bankrupt's estate under Bankruptcy Act $\$ 70$ a(5), 11 U.S.C. $\S 110$ (a) (5) (1970) as property subject to levy by the bankrupt's creditors regardless of whether there is in fact a tort claimant of the estate. This analysis would imply that the recent case of Cockerham v. Cockerham, 514 S.W.2d 150 (Tex. Civ. App. 1974), rev'd in part on other grounds, 527 S.W.2d 162 (Tex. 1975) was incorrectly decided. There, a trustee in banknuptcy was denied access to the commnnity property under the sole management and control of the non-bankrupt. In addition, even if Professor McKnight is incorrect, section 70a(5) of the Act has been more broadly interpreted than merely passing property subject to levy and sale. Carmona v. Robinson, 336 F.2d 518 (9th Cir. 1964) (sup. plemental proceedings). If no title exists in the bankrupt, or if section 70a(5) is narrowly interpreted in conjunction with a holding that snch property is not subject to levy and sale, the analysis must shift to Bankruptcy Act § 70c, 11 U.S.C. \$ 110 (c) (1970).

In this event, those versed in banknuptey matters will recognize, to their surprise and chagrin, that the question presented in Pacific Finance Corp. v. Edwards, 304 F.2d 224 (9th Cir. 1962) has arisen again despite attempts to bury it. See S. RIESEnFend, Credrtors' Remedies and Debtors' Protection 581-82 (2d ed. 1975). The question arising under Texas law when the trustee seeks to become a section 70c tort creditor was aptly put in Pacific Finance:

Does $\$ 70$, sub. $c$ vest a trustee as of the date of bankruptcy with all the rights, remedies, and powers of a creditor then holding a hen on the property of the bankrupt by legal or equitable proceedings, whether or not such a creditor actually exists, in the absence of a creditor of the bankrupt who could have obtained a kien on such property at the date of bankruptcy?

304 F.2d at 228. The court held that it did not and required the existence of an actual creditor with such a claim. Id. Thus began the controversy. See, e.g., King, Pacific Finance Corporation v. Edwards: Another Misreading of Section $70 c$ of the Bankruptcy Act, 63 Colur. L. Rev. 232 (1963); Wiley, In Defense of Pacific Finance Corp. v. Edwards, 38 REF. J. 117 (1964). Also see In re Iuther, 465 F.2d 19 (9th Cir. 1972) 
all creditors of both spouses should share pro rata in the community estate. ${ }^{259}$ Only creditors of the bankrupt should divide the separate property of the bankrupt.

\section{F. Washington}

Under the Washington property system, separate property of a spouse is under his or her sole management and control, and either spouse, acting alone, may manage and control the community personal property. ${ }^{260}$ Real property is jointly managed. ${ }^{201}$ Business transactions must be made jointly if the busmess is operated by both spouses; otherwise, the business spouse may act unilaterally. ${ }^{202}$ Claims of creditors against one spouse may not be satisfied from the separate property of the other spouse. ${ }^{203}$ Furthermore, Washington distinguishes between

(actual creditor required); United California Bank v. England, 371 F.2d 669 (9th Cir. 1966) (actual creditor required); In re Rosenberg Iron \& Metal Co., 343 F.2d 527 (7th Cir.), cert. denied, 382 U.S. 878 (1965) (hypothetical creditor sufficient). Under Texas law the question is twofold: (1) Must there be an actulal creditor? and (2) if not, can the trustee as a hypothetical creditor assume a specific status, i.e., that of a tort creditor? For discussion of a similar problem in California, see note 62 supra. If only a hypothetical creditor is needed and the trustee may assume the status of a particular type of creditor, all community property under the sole management of the non-bankrupt spouse would pass to the bankrupt's estate. If an actual creditor is required, the property solely managed by the non-bankrupt would pass to the bankrupt's estate only to the extent of the provable tort claims. The latter result was effortlessly reached in Cockerham v. Cockerham, 514 S.W.2d 150 (Tex. Civ. App. 1974), rev'd in part on other grounds, 527 S.W.2d 162 (Tex. 1975), without discussion of the problem. The question remains open because the Texas Supreme Court held that the community property in question was jointly managed by the bankrupt. Cockerham v. Cockerham, 527 S.W.2d 162, 170 (Tex. 1975).

Adopting the Pacific Finance viewpoint by allowing the trustee to reach community assets which are solely managed by the non-bankrupt spouse to the extent of the provable tort claims comports well with the intent of the Texas legislature. Moreover, if the broader interpretation of section 70c is followed, an impetus for forcing a bankruptcy will be created for non-tort creditors who wish to reap the benefits of the additional assets. Also, adoption of the Pacific Finance doctrine in this limited context seems most consistent with present bankruptcy policy as evidenced by the Proposed Act. When the Proposed Act was drafted, New Mexico allowed tort creditors of the wife to reach half of the community assets. However, the trustee under the Proposed Act, supra note 6, \$ 282 infra. Once such assets were acquired for the estate, they are distributed to all 4-601 was only able to reach such assets "to the extent of claims allowable." See note 282 infra. Once such assets are acquired for the estate, they are distributed to all creditors. Id. This result is proposed for Texas under the Bankruptcy Acl, and is consistent with the rights a trustee might exercise by proceeding under the doctrine of Francis $v$. McNeal. See text accompanying notes 162-81 supra.

259. Cockerham v. Cockerham, 527 S.W.2d 162 (Tex. 1975).

260. WASH. REv. CODE $\$ \$ 26.16 .010, .020, .030$ (1961 and Supp. 1974).

261. WASH. REV. CODE $\S \S 26.16 .030(3)$, (4) (Supp. 1974).

262. Wase. Rev. CoDe $\$ 26.16 .030(6)$ (Supp. 1974); Pixton v. Silva, 13 Wash. App. 205, 534 P.2d 135 (1975).

263. WASH. REv. CODE $\$ 26.16 .190$ (Supp. 1974) exempts a spouse's separate property from all tort claims agamst the other spouse, whether of a community nature or otherwise. WASH. REv. CODE $\$ 26.16 .200$ (Supp. 1974) further exempts a spouse's separate property from all "separate" debts of the other spouse. The only open question 
community and separate debts. Prenuptial creditors may reach only separate property of the debtor and, provided the claim is reduced to judgment within 3 years of the marriage, the community earnings and accumulations of the debtor. ${ }^{264}$ Other separate creditors are limited to the separate property of the debtor. Community creditors may reach all community property as well as the separate property of the contracting spouse. ${ }^{265}$

Bankruptcy administration in Washington prior to enactment of its new community property act was often complicated by the interrelation of Washington's community debt doctrine and section 4 of the Bankruptcy Act. ${ }^{266}$ Although the Washington courts have denied that the community is a separate and distinct entity, ${ }^{267}$ it seenus to have been common practice for bankruptcy courts sitting in Washington to allow "H and W-a marital community" to declare bankruptcy. ${ }^{268}$ In addition, there is some indication that a petition by the liusband alone could be restricted to his separate assets and liabilities. ${ }^{269}$ Both these practices should be disapproved under the new Washington community property act. ${ }^{270}$

is the liability of a spouse's separate property for a community contract debt of the other spouse. There seems, however, to be no justification to find such property liable. Cross, Equality for Spouses in Washington Community Property Law-1972 Statutory Changes, 48 Wash. L. Rev. 527, 548-50 (1973).

264. WASH. REv. CODE $\$ 26.16 .200$ (Supp. 1974).

265. It is assumed that the former rights of the husband's creditors will now be extended to include creditors of the wife as well. For an informative overview of creditors' remedies against community property under the former Washington community property law, see National Bank of Commerce v. Green, 1 Wash. App. 713, 463 P.2d 187 (1969). Also see Smyser v. Smyser, 17 Wash. 2d 301, 305, 135 P.2d 455, 457 (1943); DEFunIaK \& VAUGHN, supra note 11, \$ 158; Cross, The Community Property Law in Washington, 15 LA. L. REv. 640 (1955).

266. Bankruptcy Act $\S 4,11$ U.S.C. $\S 22$ (1970) allows only "persons" to declare bankruptcy. Bankruptcy Act $\$ 1(23), 11$ U.S.C. $\$ 1(23)$ (1970) defines person to include partnerships and corporations.

267. Household Finance Corp. v. Smith, 70 Wash. $2 d$ 401, 403, 423 P.2d 621, 622 (1967).

268. "The marital community, consisting of the husband and wife, having the capacity under the laws of Washington to incur debts, has the right to have them discharged in bankruptcy." Household Finance Corp. v. Corby, 61 Wash. 2d 184, 18687, 377 P.2d 441, 442 (1963); Kerry v. Schneider, 239 F.2d 896 (9th Cir. 1956); Moore, supra note 174 at 70 . Also consider Minder v. Gurley, 37 Wash. 2d 123, 13536,222 P.2d 185, 191-92 (1950), where the court reached the shocking result that a "community petition" which had discharged the husband and wife as a marital community also discharged the community debts vis-à-vis the husband's separate property even though the separate property had not been administered in the estate and was fully liable for such claims.

269. See In re Wallace, 22 F.2d 171 (E.D. Wash. 1927). Only separate creditors were allowed to participate in the estate although such property was equally liable for community debts.

270. Referee Moore finds it "difficult to conceive how a legally nonexistent something could be a bankrupt, possessing certain rights and privileges and charged with the 
Theoretically, a petition by "H and W-a marital community," if allowed, would pass all community property to the trustee with all community claims of both spouses chargeable against it. However, no discharge could be granted to either spouse because each spouse's separate property would remain liable for his or her debts; only the community could be discharged. The situation that would arise, as Referee Moore points out, ${ }^{271}$ would be closely analogous to partnership administration under the doctrine of Francis v. $\mathrm{McNeal}^{272}$ indicating that the separate property of the spouses should be administered in bankruptcy to afford complete relief for the debtors. However, if this step were taken, the creditors holding separate claims would have a right to participate in the distribution of the separate estate. Thus, the result would be as if the spouses had petitioned individually.

A petition by one spouse alone, restricted to his or her separate property, should also be disapproved. Although separate creditors would not be harmed by such a petition, having no rights against the community property, limiting the property of the estate to a spouse's separate property is not defensible under section 70(a)(5) of the Bankruptcy Act. Furthermore, the community creditors have a right to participate in the distribution of these assets, subject to nuarshaling considerations; hence their claims must be proved and administered in the proceeding. If this is so, a complete distribution of the assets of the bankrupt at this time seemingly would be judicially expedient. Thus, in Washington, a petition by or against a spouse should pass all the community property and the separate property of the bankrupt to the trustee. The coninuunity property should then be divided among creditors of both spouses who had access to such property under state law. ${ }^{273}$ All creditors of the bankrupt should divide the separate property.

\section{G. Summary of State Law}

Although the laws of the seven states which have enacted modern community property legislation differ in certain respects, bankruptcy proceedings should have similar characteristics in each. Assuming that each spouse has title to the community property, ${ }^{274}$ a petition by or against $^{275}$ one spouse should pass all the community property under that

performance of certain duties." Moore, supra note 174, at 71-72; also see 1 CollieR ON BANKRUPTCY If 1.19 at 120 (14th ed. 1974).

271. Moore, supra note 174, at 72-74, 77-79.

272. 228 U.S. 695 (1913). See text accompanying notes 165-68 supra.

273. Separate estate administration was already common practice in Washington. Moore, supra note 174 , at 70.

274. See notes 57 and 224 supra.

275. The test for insolvency was not discussed for each state but should be analogous to the one proposed for California. See text accompanying notes 201-02 supra. 
spouse's sole, equal, or joint control to the trustee in bankruptcy. ${ }^{276}$ Other property available for distribution to creditors should be acquired for the estate under section 70a and 70c of the Act, or excepted froin discharge. ${ }^{277}$ In every state, the community property should be distributed among creditors of both spouses who have access to such property under state law, ${ }^{278}$ while the separate property is divided pro rata among creditors of the bankrupt. ${ }^{279}$ Only the bankrupt should be discharged from his debts.

\section{$\mathrm{V}$ \\ COMMunity Property and THE Proposed BANKRUPTCY ACT}

The first section of this Part traces the administration of a bankrupt's estate in California under the proposed bankruptcy act [Proposed Act]. ${ }^{280}$ This is followed by a discussion of the sections of the Proposed Act which deal with community property and an examination of the probleins created by the recent enactment of the equal management community property laws. Finally, suggestions are nade for changes in the Proposed Act which will make administration of a bankrupt's estate under the new community property laws more equitable.

276. Community property under the sole or equal management of a spouse passes as property which may be transferred by the bankrupt. Property under the joint management of the spouses passes as property subject to levy and sale by a spouse's creditors. If the bankrupt's title is insufficient to pass all the community property to the trustee, the equitable doctrine of Francis $v$. McNeal should be invoked by the trustee. See text accompanying notes $162-81$ supra.

277. In California this includes the separate property of the non-bankrupt spouse which is liable for necessity creditor's claims and may include the community interest in the other spouse's business. See text accompanying notes 145-52 and notes 62, 208 supra. Similar results should follow vis-à-vis necessity creditors in Nevada. See text accompanying note 238 supra. In Nevada and Washington the interest of the creditors of one spouse in the business solely managed by the other spouse is unsettled; however, if such property does uot pass to the trustee automatically, but rather to the extent it is liable for provable claims, it should be collected for all creditors under section 70c of the Bankruptcy Act. In Texas, the community property under the sole management and control of the other spouse is liable for claims of tort creditors of the other spouse to the extent of provable tort claims in the estate. See note 258 supra.

278. This would be all creditors of both spouses in the states of California, Idaho and Texas. In states such as New Mexico and Nevada that allow access to at least half of the community by the separate creditors, all creditors should also share in the community assets. In Arizona, all creditors would share the community assets with the exception of separate creditors of both spouses whose claims arose prior to September 1, 1973. In Washington, only community creditors and prenuptial creditors of the spouse who reduced their claim to judgment within 3 years of marriage would divide the connmunity assets.

279. Nccessity creditors of the non-bankrupt in California and Nevada should also have rights against the separate property of the bankrupt, subject to marshaling, because they may reach such property outside the bankruptcy context.

280. See note 6 supra. 


\section{A. The Administration of a Bankrupt's Estate Under The Proposed Bankruptcy Act}

For purposes of this section, assume that a husband in California has filed a voluntary petition in bankruptcy pursuant to sections 4-201 and 4-202 of the Proposed Act. ${ }^{281}$ In addition, assume that his wife has not filed a petition in bankruptcy. Section 4-601 provides that:

(a) Property of the Estate. The following is property of the estate:

(1) all property of the debtor as of the date of the petition, except as provided in clause (5) of this subdivision;

(5) the following property owned by the debtor at the date of the petition but only to the extent stated in this clause (5):

(A) community property of the debtor and his spouse which is generally liable for the debtor's postnuptial contractual debts (other than those incurred for necessaries or as agent for his spouse) and other community property of the debtor and his spouse to the extent it is liable for any allowable claim (other than a debt for necessaries or one incurred as agent for his spouse) in the case. ${ }^{282}$

281. Proposed Act, supra note $6, \S 401$ provides that "[a]ny person . . . may file a voluntary petition under this chapter." Id. $\$ 4-202$ describes the contents of the voluntary petition and the office where such a petition is to be filed.

282. The Commission's comments regarding this section are as follows:

c. Community Property Eight states recognize a form of ownership of marital property known as community property. The rules in each state vary, making it impossible to achieve uniformity in the absence of a federal rule of property, or a limited rule apphicable only to community property states. Since no substantial reason has been suggested for departing entirely from the local law of the various community property states as to the property liable for the hus. band's debts or the wife's debts, as the case may be, the Commission recommends that community property of a debtor be included in the estate only if it is "generally liable for the debtor's postnuptial contractual debts." This preserves the result in bankruptcy which generally prevails today in most community property states. However, it is intended to overrule in bankruptcy the present result in Washington and Arizona that community property is not liable for antenuptial debts of the husband. Since under the sections dealing with claims and priorities all debts of a bankrupt are allowable, and no priority with respect to the distribution of any property is given to a postnuptial debt, such antenuptial debts would be allowed in a bankruptcy in those states and share equally with postnuptial debts, if any. The property includible would be the same even if there were no postnuptial debts, since the test for the inclusion of the commumity property in the estate is general liability to postnuptial debts, not the actual existence of such debts.

The provision recommended by the Commission also includes in the estate any other community property "to the extent it is liable for any allowable claim." This is to take care of a peculiar rule in New Mexico making onehalf of the community property liable for the vife's torts (although not her contracts). Under this provision one-half of the community would pass to the estate upon the wife's bankruptcy if there is an allowable tort claim for which it is liable, but only if there is an actual such claim and only to the extent of such claim.

REPORT: PART I, supra note 183, at 196-97 [hereinafter cited as Comments, Part $\mathrm{T}$.

7. Clause $(5)(A)$ of subdivision (a) has a special rule for community property; to the extent it comes within the rule the entire property is property 
Under this section, all the husband's separate property and all the community property pass to the trustee in bankruptcy. ${ }^{283}$ From this estate, creditors with allowable claims will be paid.

Section 4-403(b) provides the guidelines under which creditors' claims are allowed against the estate. ${ }^{284} \mathrm{~A}$ creditor is defined as "any person who owns a claim against the debtor's estate . . . ."285 Thus, under the Proposed Act, creditors of the non-bankrupt spouse should be allowed to participate in the distribution of the estate, for while they are. not creditors of the bankrupt, they do have claims against property in the debtor's estate. ${ }^{286}$ Therefore, under California law, all prenuptial and postnuptial creditors of either spouse, whether their claims were founded in contract or tort, would have allowable claims against the estate. ${ }^{287}$ Under the Proposed Act, once the claim is allowable, no priorities alnong claimants would be recognized. ${ }^{288}$ All creditors of both spouses would share the estate equally.

With this introduction, it is now possible to discuss the difficulties with the community property provisious of the Proposed Act. It should be noted, however, that the Commission drafted its proposal prior to the widespread enactment of equal management and control provisions in the community property states, and that inost of the difficulties that arise are a result of these new community property statutes.

\section{B. Analysis and Suggested Revisions for the Proposed Act}

\section{Unilateral Control by the Spouse}

One major problem with the Proposed Act is the amount of

of the estate, not just fifty per cent of the proceeds. In a community property jnrisdiction, a spouse may have "separate property" as well as au undivided imterest in "community property." Generally, the husband can dispose of community property without the consent of the wife. However, the wife generally cannot dispose of community property, and in many instances her ability to contract on behalf of the community is limited. Under $\$ 70 \mathrm{a}(5)$ of the Act, the trustee of the husband is able to administer community property that the husband could alienate. On the other hand, if only the wife files, community property is generally not administered.

Report: PART II, supra note 183, at 150 [hereinafter cited as Comments, Part II].

283. The separate property passes to the estate under Proposed Act, supra note 6, $\S 4-601$ (a)(1). The community property passes under $i d$. $\$ 4-601(\mathrm{a})(5)(\mathrm{A})$.

284. The concept of provability is eliminated under the Proposed Act. REPorr, PART II, supra note 183, at 101.

285. Proposed Act, supra note 6, § 1-102(15).

286. If this is not the proper reading of sections 4-403(b) and 1-102(15), then clarifying language should be added to the Proposed Act to ensure this result. Creditors who rightfully can reach the community assets outside the bankruptcy context must not be foreclosed from that property by the petition of the other spouse. See Part III of this Comment.

287. These ereditors may reach community assets in the bankrupt's estate. See text accompanying notes 79-86 supra.

288. See Comments. Part I, supra note 282. 
unilateral control it allows a spouse to exert over the community property under the control of both spouses. In all states with modern community property legislation, ${ }^{289}$ the community property is either jointly managed or under the equal control of each spouse; yet, the Proposed Act allows one spouse unilaterally to subject the community property to administration in bankruptcy. This fact could encourage the filing of spurious bankruptcies; ${ }^{290}$ however, no acceptable alternative is available which would totally eliminate this problem. For example, the provision could be worded so as to require a petition by both spouses in order to pass community property under their joint or equal control to the trustee. In this event, a petition by one spouse alone would pass only his or her separate property and the community property under his or her sole management and control to the trustee. This result would be unsatisfactory, however, since if the bulk of the community property were omitted from the estate, there could be no complete discharge and bankruptcy would afford only minimal relief for the debtor. Furthermore, without the bulk of the community property under the control of the trustee, the avoiding powers whieln are so necessary to protect unsecured creditors would be of hittle value. In addition, involuntary petitions would become very burdensome, requiring proof of the insolvency of both spouses before the community property would pass to the trustee. Thus, for the Proposed Act to provide total relief for the debtor, the entire community property inust pass to the trustee upon petition by either spouse. The proceedings filed for harassment purposes can be equitably dealt with on a case-by-case basis. ${ }^{291}$

\section{Statutory Construction}

Because of the recent enactments of modern community property legislation, nucle of the language of Proposed Act section 4-

289. The state of Lonisiana is not considered in this discussion. It is assumed that the Equal Rights Amendment, supra note 2, will be ratified before the Proposed Act becomes effective, necessitating a change in the Louisiana law, which presently provides for sole management of the community assets by the husband. LA. Crv. CoDE art. 23992404 (1971). Even if no change is made, the suggested amendments to the Proposed Act are easily adapted to the managerial system of Louisiana.

290. For example, a spouse who may have minimal clebts could threaten a bankruptcy proceeding on the eve of divorce in order to gain bargaining power during property settlement negotiations. This would be particularly undesirable if one spouse could unilaterally subject the other spouse's business to a trustee. However, it should be noted that in the past husbands have often used bankruptcy proceedings to proteet themselves against property settlements accompanying divorce decrees. See, e.g., In re Barasch, 439 F.2d 1393 (9th Cir. 1971); Martoff v. Elliott, 326 F.2d 204 (9th Cir. 1963). "An endeavor to substitute federal for state control does not constitute fraud." 1 CollIER oN BANKRUPTCY $\{4.03$ at 580-81 n.4 (14th ed. 1974).

291. For example, if a harassment bankruptcy is filed, the trustee could abandon that community property which is not needed to pay creditors, or could fail to pursue the non-bankrupt's business interest. 
601(a)(5)(A) is outmoded. The parenthetical exceptions to the statute, ${ }^{202}$ once needed to prevent the community property from passing to the trustee upon petition of the wife, ${ }^{293}$ are no longer necessary because the community property now generally passes to the trustee upon petition of the wife, who has management and control of the community property. In addition, the language used to pass the community property which is "generally liable" for the debtor"s postnuptial contract debts is unnecessarily ambiguous. Does "generally liable" mean subject to levy and sale? Probably not. ${ }^{294}$ If not, does it encompass community property which is liable for the claims of the bankrupt's creditors in equitable proceedings, ${ }^{295}$ or does such property pass under the second prong of section 4-601(a)(5)(A) to the extent it is liable? ${ }^{296}$ Such ambiguities should be avoided if possible, and are avoided in the recommended amendment to the Proposed Act set forth in this Comment, which focuses on the right to manage and control the community property. ${ }^{297}$

\section{Distribution of the Estate}

The greatest difficulty with the Proposed Act is caused by the changes in the community property laws that allow creditors of both spouses access to the community assets. Under the Proposed Act, the commumity property is combined with the separate property of the bankrupt to constitute the property of the estate. Claims are then allowable against the estate without priority whenever a creditor outside the bankruptcy court could have been satisfied from any portion of the assets in the property of the estate. ${ }^{298}$ Thus, because separate creditors in

292. See text accompanying note 282 supra.

293. Under the former community property law in California, the community property was not subject to levy and sale by the wife's necessity creditors, but such creditors could reach the community assets. See note 114 supra.

294. The need for the parenthetical exceptions relating to necessity creditors indicates that the term "generally liable" is broader than "subject to levy and sale." See note 293 supra.

295. For example, the assets of the non-bankrupt spouse's business in California may only be reached in equitable proceedings. See text accompanying notes 126-29 supra.

296. The final clause, which passes "other community property of the debtor and his spouse to the extent it is liable for any allowable claim . ..." was inserted to acquire the wife's one-half interest in the community property which was liable for her torts under New Mexico law. Comments, Part I, supra note 282. Now, under New Mexico's new community property law, the community property would generally pass to her trustee, making this language obsolete insofar as New Mexico is concerned. See text accompanying notes 243-50 supra. However, this language is retained in the suggested revision of the Proposed Act to deal with the business interest of the nonbankrupt spouse in California and the community property under the sole management and control of the non-bankrupt in Texas. See text accompanying notes 304-08 infra.

297. See text accompanying note 304 infra.

298. Comments, Part I, supra note 282. 
Washington may reach a portion of the bankrupt's estate, they share pro rata with the community creditors in its distribution. More interesting, however, is the result vis-à-vis creditors of the non-bankrupt spouse. Under all nodern community property laws, all creditors of the nonbankrupt, whose claims arose from activities benefiting the community, may reach the community property in the bankrupt's estate and hence share pro rata in the distribution of the estate, which contains the bankrupt's separate property and the community property. That is, creditors of the non-bankrupt divide the community property as well as the separate property of the bankrupt. Furthermore, creditors of the non-bankrupt, whose claims arose during activities not benefiting the community, can reach a portion of the community assets in all states except Washington. Therefore, they too will share in the distribution of the bankrupt's separate property with the creditors of the bankrupt. Thus, although in no state may the separate property of one spouse (the bankrupt) be taken for the payment of the other spouse's debts, this will be the result under the Proposed Act, to the detriment of the bankrupt's creditors, who will be discharged. By analogy to partnership, it will be as if the individual creditors of one partner are dividing individual assets of the other. The wisdom of this result is doubtful. ${ }^{209}$

Other inequities may also occur under the Proposed Act as presently drafted. For example, upon petition of one spouse (S1), all that spouse's separate property and the community property will pass into the bankrupt's estate (E1). A petition by the other spouse (S2) will pass only that spouse's separate property to the trustee of the second estate (E2). All creditors of the second spouse will share in the division of the first estate because they have claims agaimst the community property in that estate, with the result that they will divide S1's separate property pro rata with S1's creditors. However, because no property in S2's estate (which consists only of S2's separate property) may be reached by any of S1's creditors, only S2's creditors will divide the estate. Thus, whether or not a spouse's creditors divide the other spouse's separate property pro rata will depend upon which spouse petitions first. This cannot be a proper result.

In Washington, S1's separate creditors will share in the estate of the bankrupt (E1) because such creditors may reach separate property contained in the estate. However, on a subsequent petition by $\mathrm{S} 2$, the separate creditors of S2 can only reach the property in the estate of S2 (S2's separate property) because they have no claim agamst any property in the estate of S1. Therefore, in Washington, depending upon which spouse first files a petition, separate creditors either share pro

299. This problem also arises under the present Bankruptcy Act and is discussed in note 174 supra. 
rata in the community property or are foreclosed from sharing in it. Thus, the Proposed Act not only appropriates the separate property of the bankrupt to pay creditors of a third party who cannot reach those assets under state law, but also produces an unsymmetrical result for creditors depending upon whether their debtor files his petition before or after the other spouse. The solution to these problems does not lie in forbidding the creditors of the non-bankrupt spouse from participating in the distribution of the bankrupt's estate. As discussed earlier, to take this approach would create a great injustice to those creditors with legitimate claims on the community property ${ }^{300}$ and would itself establish an asymmetrical estate distribution dependent upon which spouse petitions first. ${ }^{301}$ The proper result is discussed in the following section.

\section{Proposed Revisions to the Proposed Act}

The solution to the problem of estate distribution under the Proposed Act is to administer the community property separately. The administrative burden of determining which property is separate and which is community is not unknown to the bankruptcy court. In fact, it already exists in bankruptcy administration under the Proposed Act, because the non-bankrupt's separate estate does not pass to the trustee and thus must be segregated from the community property. Separate administration of the community property only requires the additional task of segregating the separate property of the bankrupt. Generally, there is ample case law in each state for this determination, which is usually aided by presuniptions in favor of assets being community property. ${ }^{302}$ Moreover, with the exception of Washington, all states allow "separate" creditors to reach at least a portion of the community property. Thus no classification of the debts of the bankrupt would be necessary. All debts of the bankrupt would be chargeable against the separate estate and the community estate. All debts of the non-bankrupt would be chargeable against the community estate subject to marshaling of "separate" debts against property not in the bankrupt's estate. ${ }^{308}$ Additionally, this solution eliminates the appropriation of one spouse's separate property for the payment of the other spouse's debts and eliminates any asymmetry resulting from the order in which petitions are filed.

The following language is suggested to amend the community

300. See text accompanying note 153 and note 286 supra.

301. That is, the creditors of the spouse first declaring bankruptcy would divide the comınunity property while the creditors of the other spouse would have only the separate property of that spouse in their estate.

302. DEFUNIAK \& VAUGHN, supra note 11, at 114-211.

303. See note 186 supra. 
property provision of the proposed bankruptcy acts to deal with the preceeding problems:

4-601. (a) Property of the Estate. The following is property of the estate:

(1) all property of the debtor as of the date of the petition, except as provided in clause (5) of this subdivision:

(5) the following property owned by the debtor at the date of the petition but only to the extent stated in this clause (5):

(A) community property of the debtor and his spouse which is under the equal, joint, or sole management and control of the debtor, and other community property of the debtor and his spouse to the extent it is liable for any allowable claim in the case; provided, however, that such community property shall be administered as a distinct estate apart from other property of the estate.

The management and control language in this suggested amendment passes the same property to the estate that would pass under the present version of the Proposed Act but eliminates the ambiguous phrase "generally hable for postnuptial contract claims." ${ }^{304}$ Furthermore, the suggested language ensures that the busmess of one spouse does not automatically pass to the trustee, but gives the bankruptcy court the power to determine the extent of the liability of the business, rather than forcing the trustee to proceed against the business interest in state court. ${ }^{305} \mathrm{In}$ addition, a trustee in Texas may acquire the commumity property under the sole management and control of the other spouse to the extent such property is liable for tort claims. ${ }^{306}$ The separate administration lan-

304. See text accompanying note 294-96 supra. In every community property state, the suggested language passes all the community property owned by a debtor and his spouse with the exception of community property under the sole management and control of the non-bankrupt spouse. This community property is passed to the estate by the additional language $\mathrm{m}$ the statute "to the extent it is liable" for claims of the bankrupt, and should be read to give the bankruptcy court jurisdiction to make that determination. This language is particularly attractive in such states as California, Nevada, and Washington, where a spouse's business may be solely managed and controlled. If such states choose to make the business fully liable, the entire interest would pass to the trustee under the "to the extent it is liable" language. If such states decide to limit the hability to the "community interest," (see text accompanying notes 117-33 supra) then only that interest would pass. In Texas, the language serves to pass the community property under the sole inanagement and control of the non-bankrupt spouse to the extent that tort claimants to the estate exist. See note 258 supra. In the alternative, this additional language could be omitted, allowing the trustee to proceed under Proposed Act, supra note 6, § 4-604(b).

305. This is desirable in terms of judicial convenience because of the time delay involved with state court proceedings.

306. See note 296 supra. This would distribute such property to both tort and contract creditors of the bankrupt. Such a result is probably preferable to leaving the comnunity property under the sole management and control of the non-bankrupt spouse outside the estate and then acquiring the interest for ouly the tort creditors under Proposed 
guage eliminates the use of the bankrupt's separate estate to pay claims of the other spouse's creditors, ${ }^{307}$ but allows the non-bankrupt's creditors to share in those assets to which they rightfully have a claim. It further leaves the state law of Washington intact insofar as separate creditors would be limited to the separate estate of the bankrupt. ${ }^{308}$ Finally, the language eliminates asymmetry by providing for identical distribution to creditors, regardless of the order in which petitions are filed by the spouses.

Application of the proposed amendment in California, for example, would mean that upon a petition by the bankrupt, all a spouse's separate property would pass to the separate estate of the debtor and the community property would pass to the debtor's community property estate. The bankrupt's interest in the business of the non-bankrupt spouse would pass to the community estate to the extent that it is liable for debts of the bankrupt under state law. ${ }^{309}$ Under section 4-403(b), all claims of the bankrupt's creditors would be allowed against both estates of the bankrupt. ${ }^{310}$ Creditors of the non-bankrupt would have allowable claims against the community property estate of the bankrupt because they could reach these assets outside the bankruptcy context. ${ }^{311}$ Upon petition by the second spouse, a separate estate would be formed for that spouse's separate property, as well as a community property estate containing that spouse's business. The two community property estates should then be combined under Bankruptcy Rule $117,{ }^{312}$ for

Act, supra note $6, \S 4-604(\mathrm{~b})(2)$. It appears that a determination to distribute such property to all creditors was made by the Commission in regard to tort creditors in New Mexico (see Comments, Part I, supra note 282), and avoids the troublesome issues raised regarding community property under the sole management and control of the non-bankrupt under the Bankruptcy Act in Texas. See note 258 supra.

307. Creditors of the non-bankrupt would not have claims against property in the separate estate.

308. If Congress so chooses, it can overrule this result in Washington by providing that creditors of the bankrupt could prove their claims in both estates of the bankrupt. Such a procedure would eliminate any classification of claims of the bankrupt. However, allowing separate creditors to reach commumity assets in the bankruptcy proceeding would be an impetus for separate creditors to try to force the debtor into bankruptcy in order that they may share in the distribution of the community assets. This would make out-of-court arrangements with such creditors much more difficult. In short, because the two estates are to be administered separately in the first place, there is no reason to interfere with the state law of Washington in this matter.

309. See text accompanying notes 117-29 supra. Under Proposed Act, supra note 6 , $\$ 4-604(b)$ (2) the trustee could acquire the non-bankrupt's separate property for distribution to necessity creditors.

310. Under California law, they have claims against property in both estates. See text accompanying notes 84-86 supra. No priorities would be accorded postnuptial creditors over prenuptial creditors. Comments, Part I, supra note 282.

311. Necessity creditors of both spouses would have allowable claims against both estates of the debtor because they may reach property in the separate estate of the bankrupt. See text accompanying note 82 supra.

312. Proposed Act, supra note 6, § 4-305; BANKRUPTCY R. 117. 
they will distribute assets to exactly the same creditors. No asymmetry would exist; the trustee of the second spouse will assert the claims of all the second spouse's creditors in the other spouse's bankruptcy proceeding under section 4-403(b). None of the separate property of one spouse would be distributed to the creditors of the other spouse, and no classification of debts would be necessary beyond a determination of whether a claimant is a creditor of the husband or the wife. Administration of bankruptcy proceedings in other states would parallel this procedure. ${ }^{313}$

\section{Preferences}

In order to equitably administer the bankrupt's estate, it is necessary that the trustee have the power to collect all assets of the estate; he must be able to recover preferences and fraudulently conveyed assets, and also to avoid liens acquired just prior to the inception of bankruptcy proceedings. This must be so whether the transaction involved the bankrupt or the non-bankrupt spouse. Section 4-607 of the Proposed Act, which will replace both sections $60 \mathrm{a}$ and $67 \mathrm{a}$ of the present Act, allows the trustee to "recover property of the debtor transferred" if such property falls within the definition of a preference. For the purposes here, because the section refers to "property of the debtor," not property transferred by the debtor, it is sufficiently broad to allow the trustee of the community property ${ }^{314}$ to recover preferences by both spouses. Similarly, section 4-608, which deals with fraudulent conveyances, allows the trustee to recover "property of the debtor transferred" which falls within the definition of a fraudulent conveyance. Thus, no problem should arise concerning a trustee's power to avoid transactions of the other spouse.

\section{Discharge}

Under the Proposed Act, the bankrupt should be granted a full discharge. Separate property of the non-bankrupt which is available to creditors but which did not pass to the trustee automatically under section 4-601 of the Proposed Act ${ }^{315}$ should be collected under section

313. The property of the estate is discussed in note 304 supra. Only in Washington and in Arizona (for separate claims incurred prior to September 1, 1973) will a distinction be necessary between separate and community debts. In all other states, all creditors of the bankrupt will share in the estate, while all creditors of the non-bankrupt will share in the community estate.

314. The interests in the separate and community estates could be adverse enough to require two trustees if, for example, there were substantial reimbursement claims against the separate estate on behalf of the community. See note 91 supra.

315. For example, the separate property of the non-bankrupt spouse in California and Nevada is liable for necessity debts. 
4-604(b) of the Proposed Act for the benefit of the particular class of creditors. There is no reason to allow a discharge of any debts of the non-bankrupt spouse. ${ }^{316}$

\section{Insolvency}

The final potential trouble spot is the definition of insolvency under the Proposed Act. For the purposes relevant here, section 1$102(29)$ provides that a person is "insolvent whenever the aggregate of his property . . . is not sufficient at a fair valuation to pay his debts." This is basically the same test for insolvency as is einployed by the Bankruptcy Act. ${ }^{317}$ However, because creditors of both spouses are allowed to reach the community property, it should be niade clear that the test for insolvency takes such claims into account. ${ }^{318}$

\section{CONCLUSION}

Community property is a unique species of asset in the estate of the bankrupt. No other form of property jointly held by two or niore persons passes in its entirety to the trustee upon a petition by only one of the co-owners, is fully liable for the claims of the bankrupt's creditors, and yet is also fully liable for the claims of the non-bankrupt's creditors. For this reason, adınimistration of an estate containing cominumity property requires a unique procedure for distribution of the community assets: distribution of property of the estate to creditors of a person other than the bankrupt. The procedure for doing this under the present Bankruptcy Act is not obvious, although the necessity for accomplishing an equitable distribution to creditors of the non-bankrupt is clear. The creditors of the non-bankrupt spouse must not be foreclosed from property to which they have full access outside of bankruptcy. Hence, they should be allowed to share in the distribution of the community assets.

The Proposed Act avoids the problem of cutting off the rights of the non-bankrupt's creditors by defining a creditor in such a way as to allow all claims by persons who have claims against the property in the bankrupt's estate to sliare in its distribution. Seemingly, however, the Proposed Act may go too far, for creditors of the non-bankrupt are not only allowed to share in the community assets, but they n1ay also share in the separate property of the bankrupt, to the detriment of the bankrupt's creditors. In addition, asymmetrical distribution of assets will occur under the Proposed Act depending upon the order in which

316. See text accompanying notes 208-13 supra.

317. Bankruptcy Act \& 1(19), 11 U.S.C. \& 1(19) (1970).

318. See text accompanying notes 199-202 supra. 
spouses file petitions in bankruptcy. The statutory amendment suggested in this Comment overcomes each of these problems by providing for separate administration of the community assets, while creating only the additional burden of separating the bankrupt's separate and community property. 